\title{
New Spain's Cartography within Global Geography: José Antonio de Alzate's Maps of North America
}

\author{
José María García Redondo \\ Pablo de Olavide University \\ e-mail: jmgarciared@gmail.com \\ ORCID iD: https://orcid.org/0000-0002-4349-3306
}

Submitted: 3 February 2020. Accepted: 17 October 2020.

\begin{abstract}
Several printed versions of José Antonio de Alzate's Nuevo Mapa Geográphico de la América Septentrional (1768) are known to exist. Despite his progressive changes to the map, the Mexican polymath saw it as a single "cartographic model" that he perfected over time. This article analyses his sources and working methods, as well as his contacts with other authors in New Spain and Europe. By distinguishing between mechanisms of passive and active circulation of both resources and cartographic methods, we can note an apparent change in Alzate's practice, one which was stimulated by his interaction with, adaptation to and integration into a global geographical context.
\end{abstract}

KEYWORDS: Cartography; New Spain; Enlightenment; Cartographic Model; Circulation.

Citation / Cómo citar este artículo: García Redondo, José María (2021) "New Spain’s Cartography within Global Geography: José Antonio de Alzate's Maps of North America." Culture \& History Digital Journal, 10 (2): e018. https:// doi.org/10.3989/chdj.2021.018

RESUMEN: Cartografía de Nueva España para una Geografía global: Los mapas de Norte América de José Antonio de Alzate.- Se conocen varias versiones manuscritas e impresas del Nuevo Mapa Geográphico de la América Septentrional (1768) de José Antonio de Alzate. A pesar de los cambios que progresivamente realizó sobre el diseño original, el polímata mexicano percibió su mapa como un "modelo cartográfico" único que fue perfeccionando y corrigiendo con el tiempo. En este artículo se analizan las fuentes y los procesos de producción de sus mapas, así como su transferencia e interacción con obras y autores en Nueva España y Europa. Al distinguir los mecanismos de circulación pasiva y activa de dichos recursos y métodos cartográficos, se evidencia un aparente cambio en la práctica científica de Alzate, estimulado por la interacción, adaptación e integración de su obra en un contexto geográfico global.

PALABRAS CLAVE: Cartografía; Nueva España; Ilustración; Modelo cartográfico; Circulación.

Copyright: () 2021 CSIC. This is an open-access article distributed under the terms of the Creative Commons Attribution 4.0 International (CC BY 4.0) License. 
Historians of science have repeatedly stated that the circulation of theories, methods and products (texts, images, instruments, artefacts) is a key factor in the generation of knowledge. The generation of a corpus of knowledge which is universally accepted demands that the data and ideas generated in a given place be transferred, circulated and shared so they can be read, received, discussed, rejected and accepted. This motion implies the transformation, translation and adaptation of ideas (Livingston, 2003; Withers, 2007; Topham, 2000).

Although global scientific data flows are evidenced from the $16^{\text {th }}$ century onwards, by means of the oceanic connections established by the Iberian monarchies, the unfolding of the Enlightenment consolidated the universalist pretensions of knowledge, the institutionalisation of scientific fora and channels, and the creation of new avenues for the intellectual interaction between disperse agents in an increasingly polycentric world. Throughout the $18^{\text {th }}$ century, scientific expeditions to the colonies not only advanced knowledge in a number of disciplines but also helped to rationalise the exploitation of resources and the defence of colonial territories against external attacks (Puig-Samper, 2017, p. 908). In the field of geography, scientific practice and surveys outside Europe depended to a great extent on the cooperation and knowledge of local groups and the poorly understood environmental conditions. This posed a challenge to data verification, experimentation and the codification of knowledge in universally (Western) valid formats. As pointed out by Neil Safier (2008, p. 14), the study of "moving laboratories" or "progressive spaces", where individuals, institutions, objects and ideas interacted, allows us to dismiss the centre-periphery models and develop a more complex analysis of scientific practice and its circulation during a period of colonial expansion. In this regard, the present article distinguishes between "passive circulation" of information - that is, the one-directional transference of foreign ideas and products which can, to a greater or lesser extent, enrich local, peripheral or metropolitan knowledge - and "active circulation", understood as the multidirectional interaction that truly advances knowledge, stimulates conversation and forces the rethinking of local common places within a truly global framework of reference.

In 1793, the Creole priest and scientist José Antonio de Alzate y Ramírez (Ozumba, 1737-Ciudad de México, 1799) complained about the length of time it took for new scientific advances to reach New Spain: "What a calamity for us! Why does news concerning scientific progress reach us so late?" The reason behind his outburst was that a map of North America printed by the Royal Science Academy in Paris in 1772, and based on a map he created in 1768, did not reach Mexico until 1792. Aside from the issue of personal recognition, Alzate perceived science and geography in particular- as a collective exercise that relied on cooperation and the circulation and accumulation of individual contributions: "Any man who studies natural philosophy must know that he cannot by himself build such a huge construction; he must at least take part as a worker carrying materials."
Alzate, regarded as one of the main exponents of the Enlightenment in New Spain, was a prolific author, and he became a corresponding member of the Paris Académie Royale des Sciences, the Madrid Real Jardín Botánico and the Real Sociedad Bascongada de Amigos del País. A self-taught polymath, he disseminated his ideas and European scientific novelties through self-published newspapers: medicine, mining and literature appeared side by side with botanic and astronomic observations (Moreno de los Arcos, 1985; Saladino García, 2001, 2010; Clark, 2009a). He was greatly interested in geography and participated in contemporary debates about the shape of the earth or the exact location of the New World in the geographic coordinate system. He compared old and new data and drew maps of North America, Mexico City and other regions of New Spain (García Redondo, 2018, 2019).

Several versions, both printed and in manuscript form, of his general maps of North America exist. Although throughout his life Alzate perceived "his" map of North America as a unit that he progressively perfected and corrected, most previous studies have either focused on specific aspects or been too general, and have neglected to examine in detail the production, circulation and consumption of that cartographic model. Beginning with the original 1766 version, and then moving on to later corrections and the European printed editions (Fig. 1), this article will analyse the mechanisms of circulation, adaptation and integration of cartographic images as "science in the making" (Latour, 1987). Rather than remaining a strictly geographical artefact, maps became visual models for the dissemination and discussion of knowledge. I shall examine how Alzate's maps — which were reviewed in various places at different times- contributed (or not) to the development of the author's scientific practice, an issue on which he reflected in two articles he published on geography. ${ }^{2}$

\section{THE METHODS OF A PERIPHERAL GEOGRA- PHER}

In late March 1769, José Antonio de Alzate and Abbé Jean-Baptiste Chappe d'Auteroche met in Mexico City. The Abbé had been commissioned by the Académie Royale des Sciences to travel to the southern tip of Lower California Peninsula and observe the transit of Venus across the solar disc on 3 June. This meeting was made possible by the Spanish-French alliance; Spain was represented by the Mexican scientist Joaquín Velázquez de León and the Spain-born navy officers Vicente Doz and Salvador de Medina. The observation of this phenomenon in different parts of the world would allow for the calculation of the solar parallax and interplanetary distances (Bernabéu, 1998, pp. 21-27; Moreno Corral, 2010, pp. 2643). Less than a year earlier, Alzate had sent the Académie a Memoire sur plusieurs phenomennes de cette Nouvelle Espagne and a large manuscript map entitled Nuevo Mapa Geographico de la America Septentrional, perteneciente al virreynato de Mexico, dedicado a los sabios miembros de la Academia Real de las Ciencias de Paris (New Ge- 


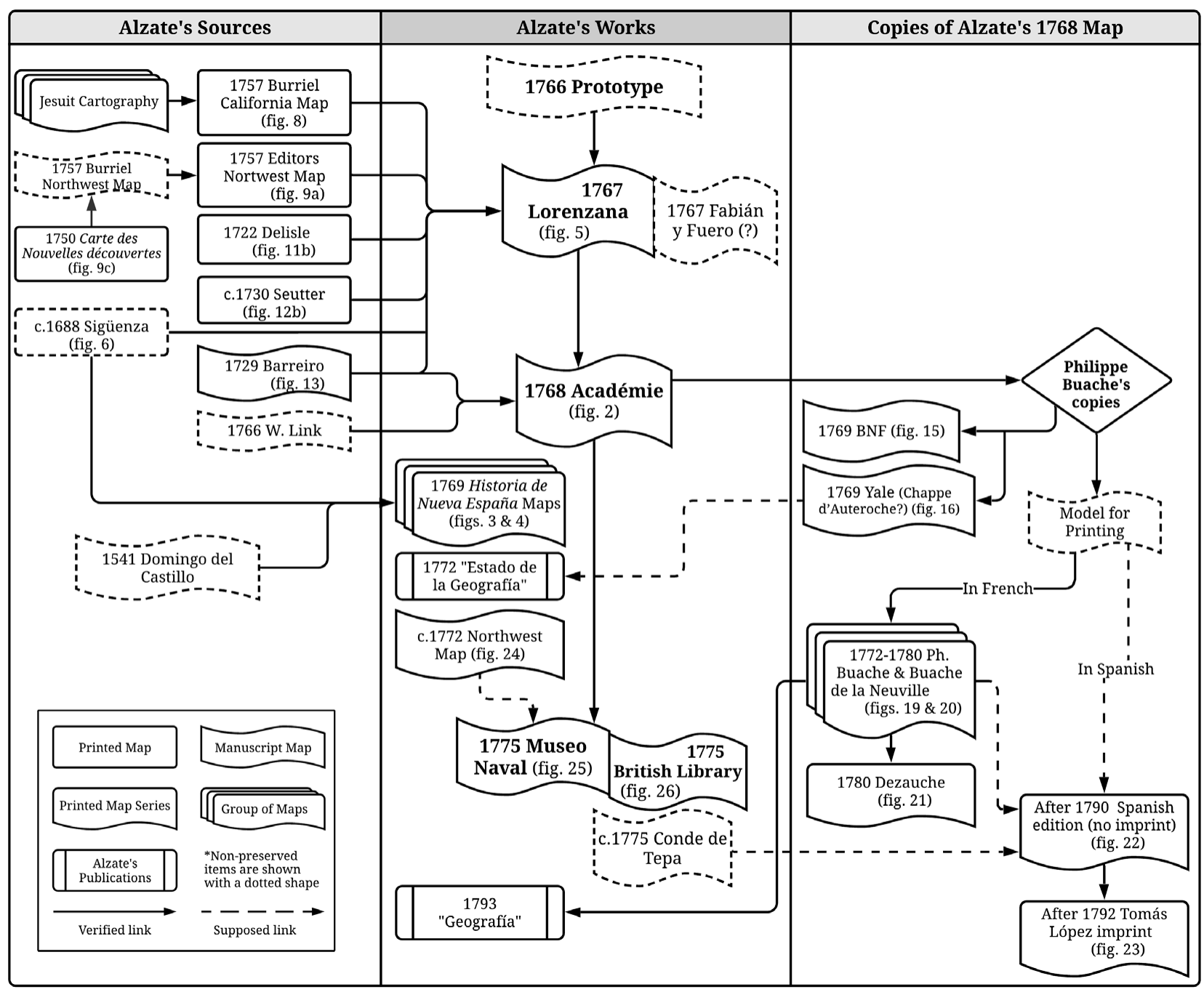

FIGURE I. Diagram with the sources and developments of Alzate's Nuevo Mapa Geographico.

ographical Map of North America, belonging to the viceroyalty of Mexico, dedicated to the knowledgeable members of the Royal Academy of Sciences of Paris) (Fig. 2) (Bret, 2001, pp. 128-129). ${ }^{3}$ Chappe d'Auteroche conveyed to Alzate the reception of his work among French academics and showed him a manuscript copy of his map drawn by the Premier Géographe du Roi, Philippe Buache (Chappe d'Auteroche, 1772, pp. 27-30). Reporting on his conversation with the Abbé, who had asked him "whether his map was based on observation or previous reports", Alzate wrote to Paris to explain his methodology as a geographer: "I did it in the latter way, and it would have been a good deal easier to do it in the former way because I was forced to read endless disperse sources, ask travellers and much more; only he who has done so can understand the obstacles." ${ }^{4}$

Alzate presented himself as a "cabinet geographer", a scholar who, isolated in his office, examines and compares previous reports as well as the observations of his own informants. For him, research was a cumulative process based on a variety of sources (Achim, 2012, pp. 27-
28). His complex web of informants included local priests -who were referred to as "connoisseurs", although some were "lacking in any talent" for geography - because they knew the territory, "and who but them are the fittest to form this building?" However, through his readings, which included a large number of up-to-date publications in French and English, Alzate knew of the consolidation of the idea of the scientist as a member of a global community in which practical experience — experiments - with perfectly calibrated and expertly handled instruments was given priority over bookish erudition (Valverde, 2007, pp. 13-16). For this reason, he felt the need to justify the validity of his sources, compiled by "very able persons", and he explained his lack of hands-on experience as a consequence of his professional duties in Mexico City. ${ }^{6}$

Aware of his peripheral position, Alzate also argued that he did not have the support of a local scientific network to promote progress in New Spain. He also decried censorship, bureaucratic barriers, the lack of protection of scientists and the lack of funds (Moreno de los Arcos, 1985, pp. 1-29; Bret, 2001, pp. 135-137). More than any- 


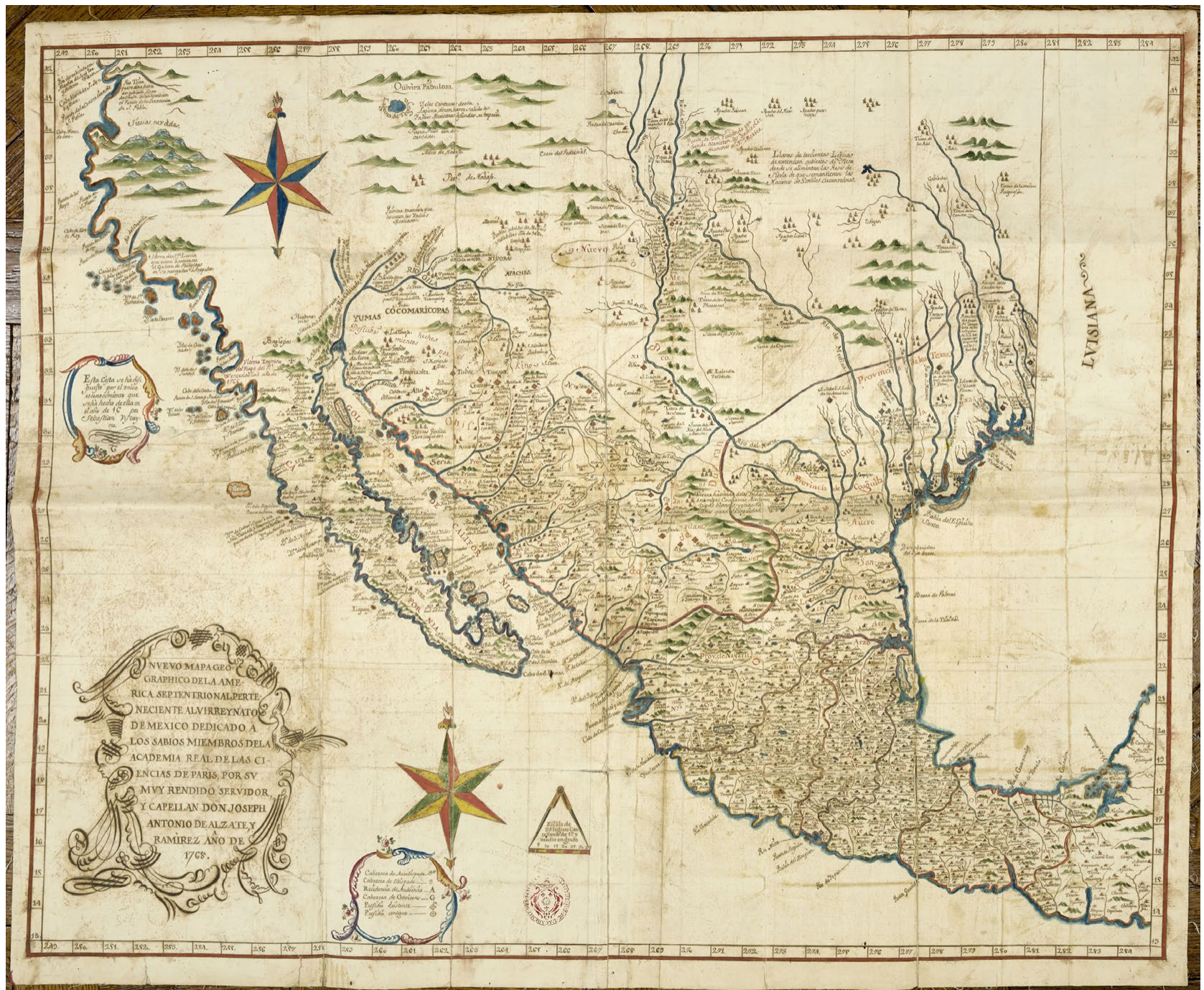

Figure 2. Alzate, Nuevo Mapa Geographico de la America Septentrional, perteneciente al virreynato de Mexico, dedicado a los sabios miembros de la Academia Real de las Ciencias de Paris, 1768. Bibliothèque d'Institut de France, Paris. Reproduced with permission.

thing else, he complained about the lack of "the necessary instruments; those that we have we have built with our own hands." $\mathrm{He}$ recognised that his observations could not be considered "complete" and compared badly to the "delicate" observations undertaken by European scientists, who had "good instruments" which "in New Spain we can only wish for because they are neither for sale nor can we make them as they require experienced masters, and even they make one good instrument for many that do not come out right" (Alzate, 1770, pp. 14-15).

In the late $18^{\text {th }}$ century, the use of scientific instruments conferred authority and objectivity on the observation of natural phenomena, even outside strictly academic circles. In the context of the generation of knowledge, instruments were perceived as mediators between the observer and the world and between observers because they provided replicable and comparable data (Schaffer, 2011 , p. 285). In the context of the controversy between Joaquín Velázquez de León (Ciudad de México,
1732-1786) and Alzate over the observation of Jupiter's satellites, the former criticised the results of the latter by pointing out that "the ability of the observer is not enough, but the instruments must also help [...] and Alzate admits that many of his instruments have been made here under his instructions. I have not seen them, and I am sure that they are fine, but I cannot believe that they are as good as Dollond's, Canivet's and Berthoud's, which are the ones I used" (Velázquez, 1775, p. 210).

By offering visual representations of the territory, astronomical observations allowed for objective data to be generated. Alzate was aware that "the best thing for the map to be as perfect as possible" was to walk, "instrument in hand, taking angles and distances, and making astronomical observations." However, at first Alzate compensated for this shortcoming with a host of reports from his "connoisseurs", which is "the only way when geometrical measurements and astronomical observations are lacking." Imitating European erudite scholars, he dis- 
dained practical work and tried to evaluate the validity of his sources. He also thought that his work was "the least bad of this country's production" because he knew that "many others have used my maps and found them exact." However, as checking the reliability of his sources was impossible, he ended up constructing an impossible and polyphonic "total image" of New Spain, a veritable "cartographic patchwork." The system of "passive circulation" in which he participated during his early years the compilation and promiscuous assembling of multiple representations - determined a visual scientific practice which was rooted in the Baroque tendency to accumulate images and "images full of things" (Marcaida, 2014, p. 56).

Alzate was not a geographer or an astronomer by training, but he was nevertheless systematic and reflective (Moreno Corral, 2010, pp. 25-26). He recognised that his training was not based on teaching but on reading European books. ${ }^{10}$ In France, Anne Godlewska (1999, pp. 28-30) found other men who, like Alzate, aspired to be accepted as geographers and for their work to be accepted as "geography." Aware that there was a hierarchical structure of knowledge, at the top of which were European institutions, Alzate tried to grow out of being an autonomous geographer to become a "networked" researcher and part of the global research community as a "scientist/bureaucrat."11

That is why it was so important for him to make his work known across the Atlantic and to send even the smallest new piece of information. In 1770, along with the report on the elaboration of his map and Memoire, requested by Chappe d'Auteroche, Alzate sent to Paris the results of his own observations of the transit of Venus from Mexico City — which he made in the company of the erudite scholars José Ignacio Bertolache and Antonio de León y Gama (Moreno Corral, 2010, p. 36) - as well as numerous prints on astronomy, followed soon after by a collection of natural history specimens (Bret, 2001, p. 148). Also included was a map of Mexico City that he had made himself, and a copy of a 1541 map made by the pilot Domingo del Castillo during Hernán Cortés's expedition to California (Fig. 3). ${ }^{12}$ Copied by Alzate, the map was engraved in 1769 by José Mariano Navarro for Hernán Cortes's Historia de Nueva España, edited by Archbishop Lorenzana in $1770 .{ }^{13}$ For Alzate, this document proved that Spaniards had accurately identified California as early as the $16^{\text {th }}$ century, but, as they did not share the information, it was mistakenly represented as an island for more than a century (Polk, 1995): "should this map have been published in due course, all the controversies around California would have come to an end because [the map] clearly shows that it was acknowledged as a peninsula from the start, which has recently been proven." 14

However, Alzate did not send the Académie a second map that he had prepared for Cortes's Historia: a historical cartography including the voyages of New Spain's conquistador (Fig. 4). ${ }^{15}$ This is almost a replica of Carlos de Sigüenza y Góngora's cartographic model (c. 1688) which often features among Alzate's sources. Neverthe-

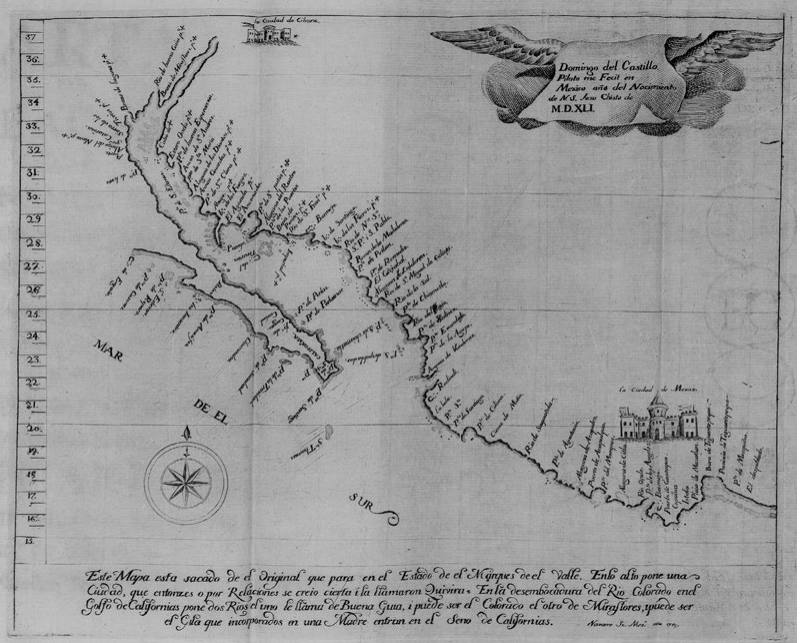

Figure 3. Alzate, Mapa del Mar del Sur del piloto Domingo del Castillo de 1541. Lorenzana, 1770.

less, in this case Alzate did not share this document with the French academics. When he broadcast his works outside the viceroyalty of New Spain, Alzate became more mindful of his style and measured his words a good deal more. There is little doubt that his work changed after his first dispatches to the Académie in 1768, and these changes become even clearer after his meeting with Chappe d'Auteroche and the observation and astronomical measurement of the transit of Venus and other celestial phenomena in 1769 . These events made him a more mature researcher and prompted him to use mathematics and astronomy more profusely in his cartographic practice.

\section{A CARTOGRAPHIC PATCHWORK: THE NUE- VO MAPA GEOGRÁPHICO, EL MÁS COMPLETO Y ACOTADO (1767)}

The Nuevo Mapa Geográphico, el más completo y acotado de cuantos se han publicado de la América Septentrional Española, dividida en Obispados y Provincias (New Geographical Map, the most complete and

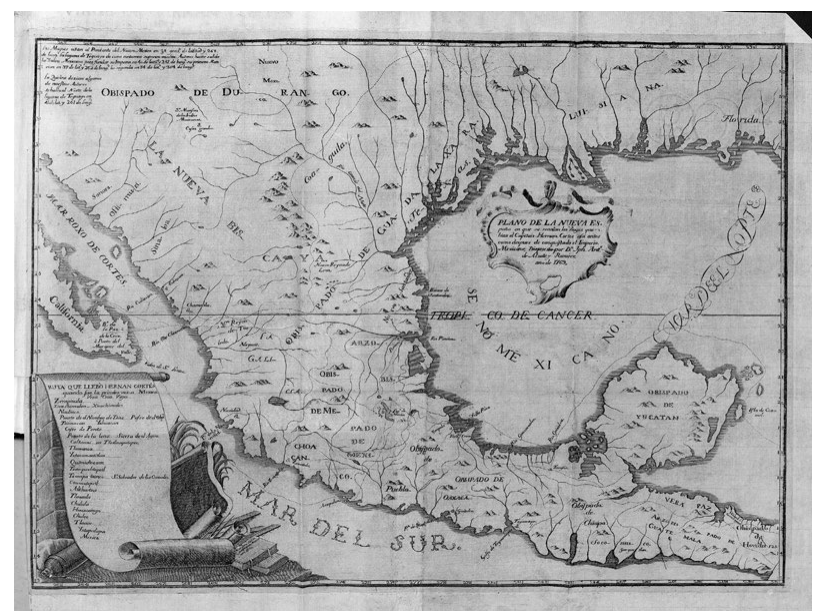

Figure 4. Alzate, Plano de la Nueva España en que se señalan los viages que hizo el capitán Hernán Cortés. Lorenzana, 1770. 
accurate of all published maps of Spanish North America, being divided into dioceses and provinces), is the earliest of José Antonio de Alzate's maps of North America (Fig. 5). ${ }^{16}$ It was dedicated to Archbishop Lorenzana (whose coat of arms appears in the top) in 1767, the same year that Alzate began working for him, rearranging the parishes in Mexico City. The map may have arrived to Spain in 1772 with the other documents that Lorenzana brought from Mexico when he was appointed Archbishop of Toledo (Esteve Barba, 1942). Some time later, it passed to the Depósito Hidrográfico de la Marina, an institution created in the late $18^{\text {th }}$ century and which was to carry out significant cartographic work (Martín-Merás, 1993, p. 222). When this institution was disbanded in the early 1930s, the map was transferred to the collection of a renewed Madrid Museo Naval, and was catalogued by the assistant director, Admiral Julio Guillén Tato (Moreno Martín, 2012, pp. 142-143). The map was displayed in public in 1932, for the Museo Naval's first exhibition, 400 years after the first voyage to the coasts of California (Guillén, 1932 , pp. 15, 106)
It is likely that the map was an adaptation of the prototype that Alzate claimed he made in 1766, "copies of which are in the possession of some of my patrons." 17 Roberto Moreno de los Arcos (1985, p. 31) pointed out that one of these copies went to the Bishop of Puebla, Francisco Fabián y Fuero. Although Alzate conceived these works as "very imperfect drafts," itate to entitle his 1767 and 1768 versions a "new map", revealing his ambition to update the image of the whole of North America (Carrera, 2011, p. 112).

The Nuevo Mapa Geográphico is an information-rich "representation of representations" presenting a wide variety of (sometimes contradictory) images and sources. The map presents and describes the territory of New Spain (including provincial and diocesan boundaries), but also includes a number of smaller maps - on a different scale - of other territories that fall outside the map's margins. A large number of texts make reference to the history, population and discovery of each territory. In order to combine the cartographic representation with images of the local natural environment, Alzate included

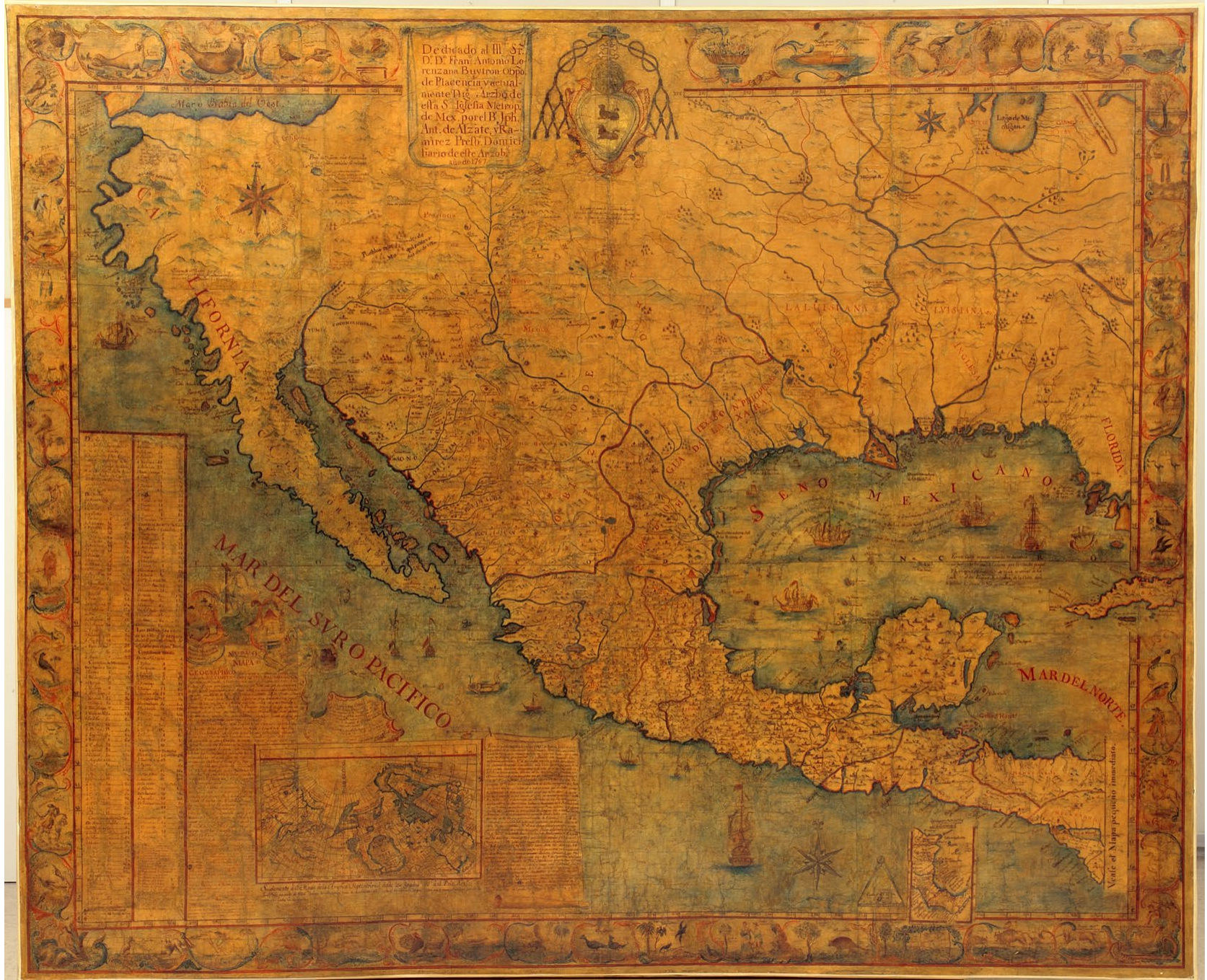

FIGURE 5. Alzate, Nuevo Mapa Geográphico, el más completo y acotado de cuantos se han publicado de la América Septentrional Española, 1767. Museo Naval, Madrid. Reproduced with permission. 
a frame with 50 vignettes which represented the flora, fauna and human groups that inhabited New Spain. This Baroque exhibition (in a single image) of total and synoptic knowledge also includes a representation of the author, an explanation of his scientific methodology and his research goals: the cartouches with his signature, his explanations and sources have "authenticating effects that valorize the execution of and the labor" invested in the researching, measuring and drawing of the map (Conley, 1997, p. 21).

In the main cartouche (only some of which is legible because the paper is worn), Alzate states that he has used numerous general and local maps, both Spanish and foreign, "taking what I have found most useful because wide variations exist, both in terms of distances and directions." Demonstrating his ability as a cabinet geographer, he quotes foreign authors from the $16^{\text {th }}$ century to his own time, including Abraham Ortelius, Matthäus Seutter, Willem Janszoon (or Joan) Blaeu, Nicolas Sanson, Guillaume Delisle and Nicolas (or Antoine) de Fer. In this same space, he reviews the work of local cartographers: he rejects the work of the "extravagant" mathematician José Antonio de Villaseñor y Sánchez (San Luis Potosí, 1703-Ciudad de México, 1754), whose Theatro americano (1746-1748) is nothing more than a "mix of contradictions, frivolities and whims," 19 but he praises the engineer Francisco Álvarez Barreiro and the astronomer and writer Carlos de Sigüenza y Góngora (Ciudad de México, 16451700), professor of mathematics and astrology at the Real y Pontificia Universidad de México. ${ }^{20}$

Although it was nearly one hundred years old and had a limited geographical scope, Alzate considered Carlos de Sigüenza's lost Descripzion Geographica de la America Septentrional (c. 1688) the "main source" for his 1766 design. Although there is evidence that a version of this map existed in the viceroy's palace, having been confiscated from the collector Lorenzo Boturini Benaduci (Codding, 1994, p. 189), Alzate may have had his own copy. Velázquez de León $(1775$, p. 194) claimed never to have seen it "because it was in the hands of Don José de Alzate." He, however, accused Alzate of copying Sigüenza, saying that "Alzate's 1766 map is very much composed as an exact replica of Sigüenza's." Alexander von Humboldt (1811b, I, p. 98) repeated this accusation when he referred to Alzate's map as "Sigüenza's, but the Académie in Paris has engraved it under Alzate's name; it is the best map of Mexico that we have seen to date."

Despite its rudimentary design, Alzate praised Sigüenza's map's usefulness because of its great "accuracy in describing such a large portion of America, so much so that you forgive the mistakes." ${ }^{21}$ He appreciated Sigüenza placing Mexico City at a latitude of $19^{\circ} 23^{\prime} \mathrm{N}$, which was closer to what he had calculated shortly before $\left(19^{\circ} 54^{\prime} \mathrm{N}\right)$ than the conventional $20^{\circ} \mathrm{N}$ used by most European maps. However, Velázquez de León (1775, p. 194; Moreno de los Arcos, 1977, pp. 142-143), looking at other documents, estimated that, in fact, the position calculated by Sigüenza was $19^{\circ} 15^{\prime} \mathrm{N}$, challenging Alzate's interpretation: "I suspect that the irregularities of the paper and the compass points can cause, depending on size,

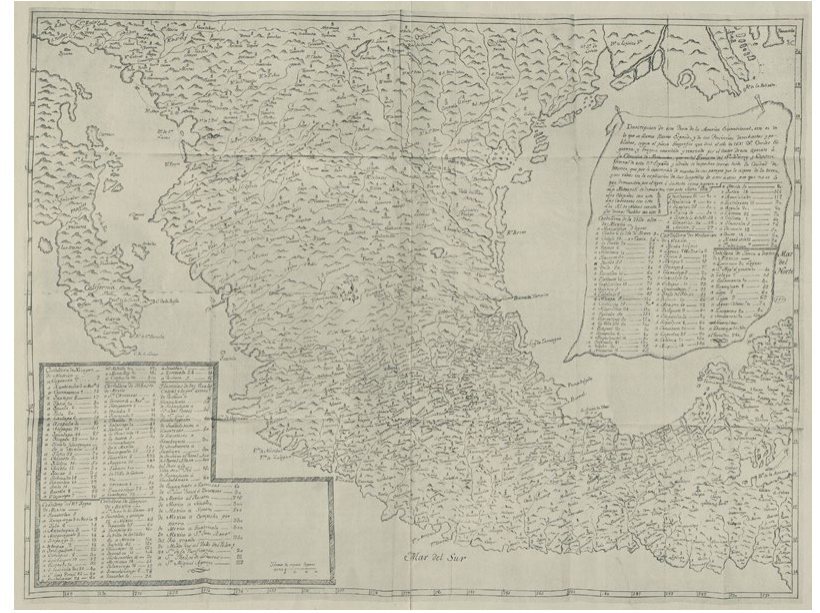

FIGURE 6. Beaumont's version of Sigüenza's map (c. 1688), Descripción de esta Parte de la America Septentrional... según el plano Geográfico [de] Carlos Sigüenza y Góngora, c. 1778 (1873 copy). Museo Naval, Madrid. Reproduced with permission.

that error of eight minutes." We now know the modified version of Sigüenza's map drawn by the Franciscan Pablo Beaumont around 1778 for his Aparato a la Chronica de Michoacán (Trabulse, 2001, pp. 269-270) (Fig. 6). ${ }^{22}$

Alzate also used Sigüenza as a source for his "Description of this part of North America [...] the Viceroyalty of New Spain, whence the post and commissars of the Royal Finances depart, Mexico City, the capital, which is the starting point of the following cordilleras": On the left side of the Nuevo Mapa Geográphico, in two columns, is an inventory of routes or cordilleras (in-line roads): the name of each city is followed by the number of leagues that separate it from the city in the previous line and the distance to the capital (Fig. 7). The toponyms are divided into seven lists, corresponding to the cordilleras or routes that connected the regions of New Spain: Villa-Alta, Michoacán, Tierra Adentro, Jicayán, Nuevo Reino de León, Tabasco and Tampico. The eighth list corresponds to the "Atravesías (journeys) of the cajas reales (royal tills) and some extraordinary places", and these roads are signalled using economic and political —rather than regional- criteria. For instance, the list features the distance to reales de minas (mining towns), frontier points in northern New Spain and other peripheral locations, such as Guatemala and Campeche.

Although Alzate does not credit the source of this information on the map, 30 years later he conceded that, in 1763, he had bought a copy of the cordilleras from an elderly Tomás de Sigüenza, nephew of Carlos de Sigüen$\mathrm{za}$, who had made several copies of it in the late $17^{\text {th }}$ century (Trabulse, 2001, pp. 272-274). ${ }^{23}$ Alzate reproduced - with slight corrections - the same lists that he had used for the manuscript map, to which he added a "warning note" with instructions to read them properly. ${ }^{24}$ In the cordilleras printed version, he included the direction or relative position of each place with regard to Mexico City (to the north, south, east, west, etc.), information that he omitted from the list in the Nuevo Mapa Geográphico. 


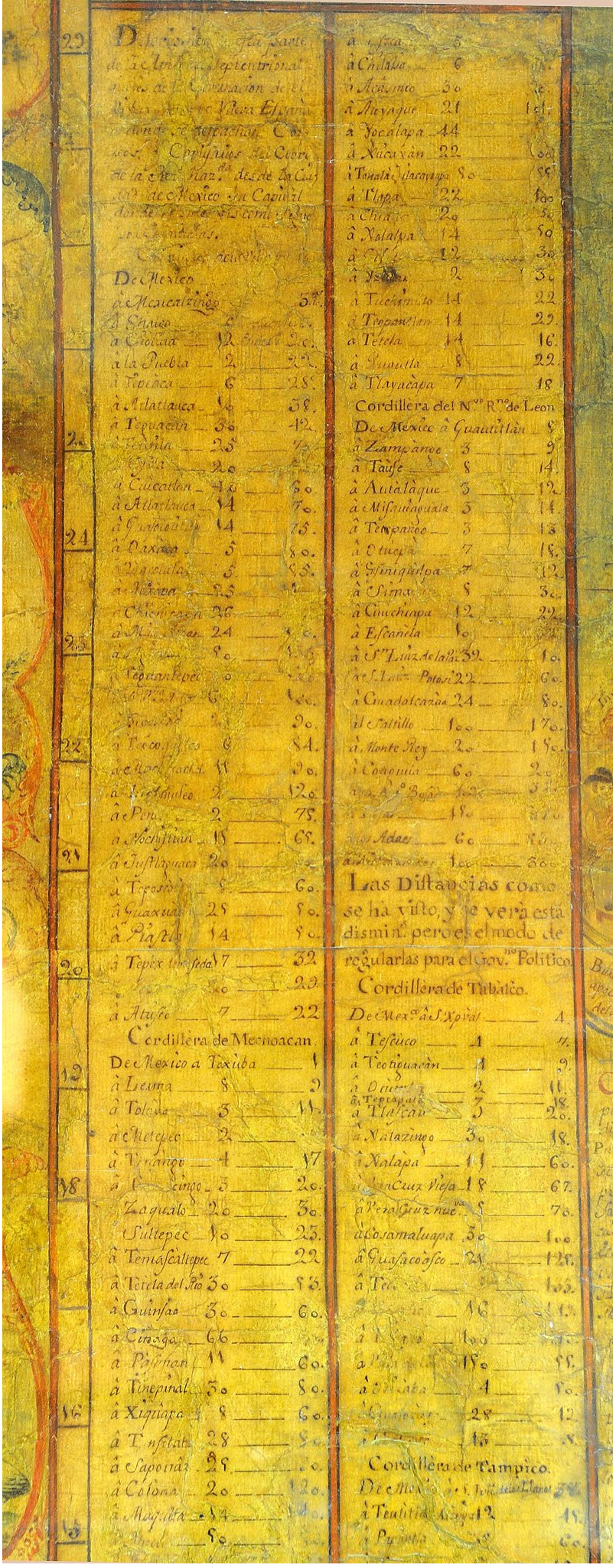

Figure 7. Cordilleras detail in Alzate, Nuevo Mapa Geográphico..., 1767. Museo Naval, Madrid. Reproduced with permission.

The textual description of these references is indicative of Alzate's preference for the visual; he regarded geography as a "science that enters through the eyes." These written references were meant to orient the viewer and give them "a better understanding"; they did not aspire to perfection "in mathematical terms, but only as an approximation." In this way, he aimed to help the traveller that used each cordillera to develop a mental map of New Spain: "even if they are not geographical descriptions, the reader will know more or less in which direction he is travelling, and how far each place is from Mexico City." 25

Like Alzate, Pablo Beaumont also produced his own version of Sigüenza's map including the cordilleras, although it is likely that, originally, both documents were independent (Trabulse, 2001, pp. 273-274). The aim of including these tables was to add a geographical dimension that could not otherwise be represented, owing to the scale and available graphic sources: the winding nature of the roads, the real distances between places and, in practice, the time it took to travel those routes. Beaumont explained the inclusion of these lists "because of the inaccessible nature of many places, the unforgiving nature of the land, and its roundabouts", making a distinction between abstract or cartographical longitude and real distance: "an explanation on the distances between one place and another is included, since they are not what they appear by air or in a straight line." Thinking about his patron the archbishop, Alzate annotated between the columns that "the distances, as will be shown, are reduced, but it is the only way to make them useful for the government." By admitting that these figures were conventional rather than accurate, Alzate did not correct Sigüenza but presented his own conversion rule: "All difficulties are solved by adding a third or a fourth: for instance, the distance between Mexico City and Xochimilco is expressed as 4 leagues, when in reality it is 5; from Mexico to Toluca, 12 leagues, when it is 16 , etc." 26

To represent the northwest territories, Alzate used Jesuit maps, although he did not credit them explicitly. This may have had to do with the position of the Society of Jesus in the territories of the Spanish monarchy, from which it had been expelled in 1767. From the late $17^{\text {th }}$ century onwards, the Jesuits had been travelling in the northern regions of New Spain, making observations and drawing competent maps: they confirmed, again, that California was a peninsula and not an island, as was wrongly believed (León-Portilla, 2001, pp. 105-131). The French academics that examined Alzate's 1768 map (see Fig. 2) pointed out that the eastern coast of the Gulf and the courses of Rivers Colorado and Gila were inspired by the maps made in 1701 by Father Eusebio Francisco Kino, who confirmed the "terrestrial access route to California." However, the academics clarified that they had realised this thanks to Guillaume Delisle's maps, ${ }^{27}$ which have been credited with disseminating the new image of the peninsula before Kino's account was known (Dawson, 2000 , p. 43 ; Broc, 1975 , p. 168). For the outline of the peninsula, however, Alzate followed the cartography of Father Ferdinand Konščak (1746), which was much more detailed than Kino's (Altić, 2012, p. 11).

Alzate also minimised references to Jesuit maps in his texts: he barely mentions the "great assistance" lent 
by the maps of Sonora, Sinaloa, Nayarit and Nuevo México, which were "made by some missionaries", and he also says that "the map of California printed in Madrid is reasonably good." 28 In this quote, he was probably referring to the Mapa de la California, su Golfo y Provincias fronteras en el Continente de Nueva España, published in the edition of Father Miguel Venegas's Noticia de la California, published in 1757 by Father Andrés Marcos Burriel (Fig. 8). This image was a key and up-to-date source for the data collected by Father Konščak: the toponymy, outline and position of the peninsula of California are identical to those expressed by Alzate in 1767. For instance, Cabo San Lucas is present on both maps towards $22^{\circ} 10^{\prime} \mathrm{N}$. However, in the edition that Alzate sent the Académie the following year (Fig. 2), the southern tip of the peninsula is much less prominent, and located at $21^{\circ} 50^{\prime} \mathrm{N}$. This new description of the peninsula caused a stir among academics, who asked for "reports" on the sources used by Alzate:

California [...] appears to have a different shape. The two coasts that form it and their outline seem to have been recognised; they converge towards one another, making the peninsula shorter than thought. Cape San Lucas, which is the southernmost tip and which on previous maps was located to $23^{\circ}$ and a half, is here marked to under $22^{\circ}$; that is, one degree and a half more to the south, making it much closer to Cape Corrientes and stretching California. ${ }^{29}$

Alzate furthermore used the Mapa de la América Septentrional, y Asia oriental y Mar del Sur intermedio,

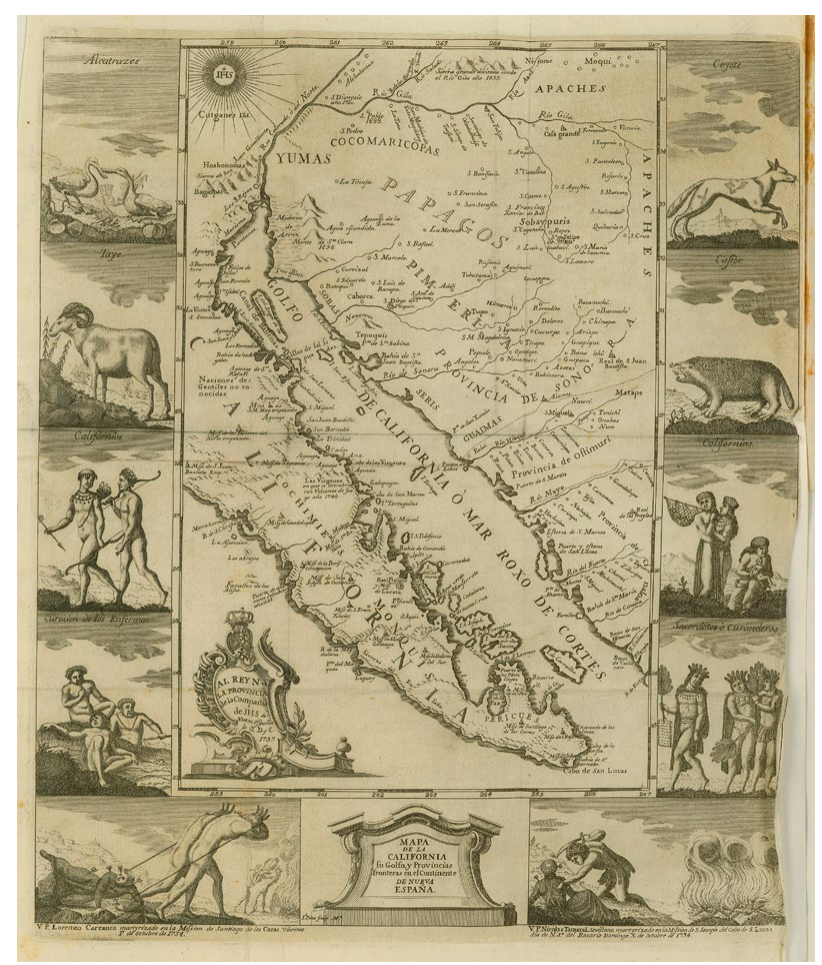

Figure 8. Mapa de la California, su Golfo y Provincias fronteras en el Continente de Nueva España. Burriel, 1757. Courtesy of the John Carter Brown Library, Providence. formado sobre las Memorias más recientes y exactas hasta el año de 1754 (Fig. 9a), also published in the Noticia de la California (Burriel, 1757), and his approach fell between erudition and plagiarism. This map was his source for a small map presented in the lower section of his work and entitled "Suplemento a el Mapa de la América Septentrional desde los grados 46 a el Polo Ártico" (Supplement to the Map of North America from 46 degrees to the Arctic Pole) (Fig. 9b). Alzate kept the original conical projection, but reduced the latitude of the original map by 20 degrees. The function of this "map within a map" is twofold: first, it updates the geographical information using new data, which "was produced by the Muscovites in 1766 after their discoveries from [north]east to America, which have been included here owing to their singular nature"; and second, it represents the area that was left outside the general map. There is, however, a 2-degree deviation between both maps: for instance, the opening of the hypothetical Sea of the West is situated at $43^{\circ} \mathrm{N}$ on the main map, and at $45^{\circ} \mathrm{N}$ in the "Suplemento." In any case, the process of the creation and transmission of the Mapa de la América Septentrional played a key role in the mistakes made and cartographic strategies used by Alzate.

The last volume of the Noticia de la California contained an extensive Appendix that deals with recent expeditions to the northern Pacific, an area in which the economic, religious and political interest of Spain, Britain, France and Russia converged (Bernabéu, 1991, pp. 104-111). In this volume, Burriel (1757, III, p. 18) harshly criticised the geographical fantasies about the outline of the American continent disseminated by European cartography, and accused academics in London and Paris of believing Admiral Bartolomé Fonte's fabulous account (supposedly dated 1640); he argued that there was sufficient evidence to claim that this account "was apocryphal and false, and intentionally deceiving." The Jesuit also dismissed the popular Carte des Nouvelles découvertes au Nord de la Mer du Sud, tant à l'Est de la Siberie et $d u$ Kamtchatka, qu'à l'Ouest de la Nouvelle France (Fig. 9c), which Nicolas Delisle and Philippe Buache presented to the Académie in Paris in 1750 along with a geographic report (Pedley, 1992, pp. 74-76). In these documents, these illustrious geographers reported on the Russian discoveries - for instance Bering's and Steller's - in the northern Pacific, but also gave credit to Admiral De Fonte's geography: for instance, the above noted Sea of the West. Throughout the $18^{\text {th }}$ century, this mythical sea and the supposed Strait of Anian - which linked the Atlantic and the Pacific - consolidated as a grande probabilité among the most prestigious European geographers (Pimentel, 2003, pp. 138-141; Broc, 1975, pp. 152-166). Alternatively, after comparing the "safest accounts, both old and recent”, Burriel (1757, III, pp. 16, 19) crafted a corrected version of the aforementioned Carte des Nouvelles découvertes: "the truth of this matter is what is ascertained in this book, and thus it is depicted in the map."

Unfortunately, it was not the map corrected by Burriel that was printed in Madrid in 1757. In early 1758, the Jesuit complained because Francisco Rivera —one of the 

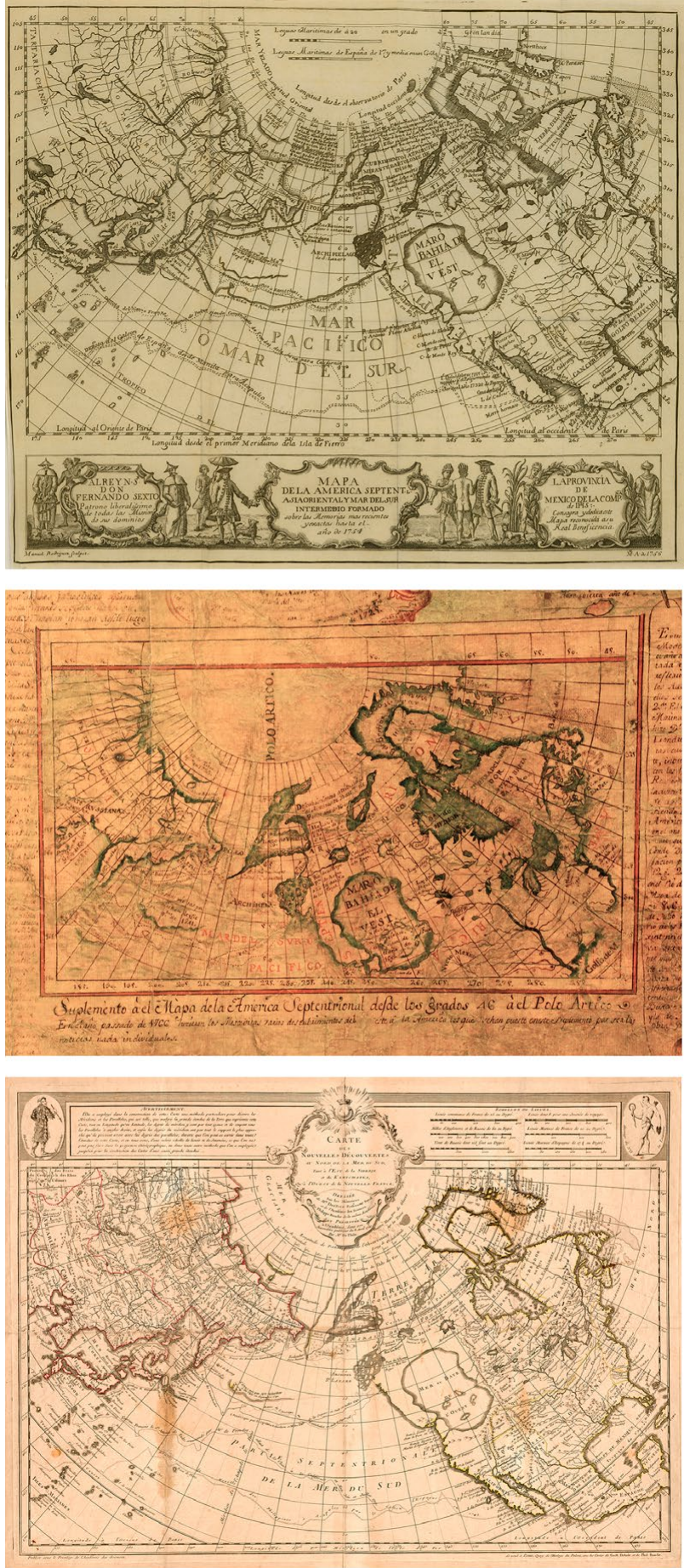

Figure 9. (a) Mapa de la América Septentrional, y Asia oriental y Mar del Sur intermedio, formado sobre las Memorias más recientes y exactas hasta el año de 1754 (Burriel, 1757). (b) "Suplemento a el Mapa de la América Septentrional desde los grados 46 a el Polo Ártico" (Alzate, Nuevo Mapa Geográphico..., 1767). (c) Delisle \& Buache, Carte des Nouvelles découvertes au Nord de la Mer du Sud, 1750. Courtesy of the John Carter Brown Library, Providence. three censors of Noticia - had altered without his permission the newly-made map, and in its place, had printed "a copy of the one by Monsieur Buache, whom I mock", contradicting the explanation in the Appendix. Burriel also protested about the fantasies and mistakes added to his book: "what is most commendable in my work has been deleted - among other things, all my corrections to Monsieur Bellin - and a map that does not match my work has been included" (cit. by Burrus, 1967, pp. 210-211). Burriel's corrected map has not survived, but some clues suggest that there was a large blank space over northwest America, an uncomfortable gap that the editors "rectified" arbitrarily. When Burriel addressed his possible detractors about the area "from the end of California, Cabo Blanco, Río de Martín Aguilar, Río Colorado, Moqui and New Mexico to the north, for an extension of 50 degrees", he referred to this area as "the large expanse of America, which on our map is encompassed by a dotted line" (which seems to have outlasted into the printed map as a dotted line that runs to the northeast from Cabo Blanco, right below the hypothetical Sea of the West); a clearly defined territory about which Burriel (1757, III, p. 436) said: "Unknown. Nescio. I know not."

As a result, the editor's "amended" map and Burriel's Appendix were contradictory. This explains that Alzate copied the wrong graphical information on his map while assuming Burriel's criticism on his cartouche texts. Following Philippe Buache's geography (1754), Alzate pointed out "the strait discovered by Juan de Fúcar in 1592" and the "river discovered by Martín de Aguilar and Antonio Flores in 1602", which led to Mar o Bahía del West. In the "Suplemento" (Fig. 9b), he added legends similar to those on the "amended" map (Fig. 9a) relating to Juan de Fuca and Admiral Fonte, and in the map's frontispiece he copied the references to Vitus Bering's 1729 voyage and the English search for a route to the Pacific ocean in Hudson Bay in 1746. These texts featured only in the Spanish version of Carte des Nouvelles découvertes (Fig. 9a) (Pinzón, 2017 , p. 28), so there is little doubt that this was Alzate's source. Alzate also used Burriel's critical arguments (1757, pp. 287-436), which he added in a large cartouche to the right of the "Suplemento." Without crediting the author, he summarised the mistakes, anachronisms and inconsistencies that Burriel criticised about Fonte's apocryphal account. Alzate condemned "the lies that Monsieur Buache and Monsieur Delisle presented to the Académie in Paris", later disseminated through French and English maps. Thus, even though he criticised the geographical "tricks" in the legend of the map, Alzate drew the very same geomythologies in his Nuevo Mapa Geográphico.

With totalising perspective, Alzate also added another small map of the Isthmus of Panama, which fell outside the main map's frame. A straight line with the legend "see the small map to the side" over Honduras and Nicaragua points the reader to this "little map", which has its own scale and coordinates, and includes Portobelo and Panama Bay, on a longitude of $299^{\circ}$ (Fig. 10). On the margins, he also drew part of Cuba and the nearby island of Pinos and the Cayman Islands. 


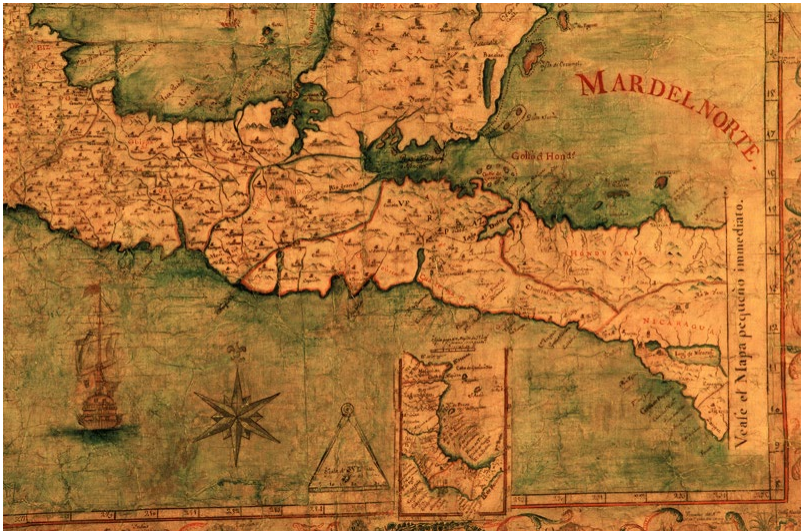

Figure io. Little map and Isthmus of Panama in Alzate, Nuevo Mapa Geográphico..., 1767. Museo Naval, Madrid, 1767. Reproduced with permission.

Alzate was also interested in conveying nautical information. A thin dotted line pointed out shallow waters around the islands mentioned above and the coasts of Yucatan and Honduras. In the Gulf of Mexico, a note explains how to calculate the distance to the coast based on sea depth: "In this Gulf, the distance to the coast can be calculated by depth sounding e. g. if there are six fathoms of water, the distance to the coast is seven leagues, as pointed out by Guillermo Le Ysla in his map." ${ }^{30}$ His source was Carte du Mexique et de la Floride... et des Environs de la Riviere de Mississipi (Amsterdam, 1722), on which Delisle engraved "Dans ce Golfe ou Baye on peut connaitre la distance ou l'on est de la Terre en sondant la Profondeur; Car on en est eloigné d'autant de Lieues qu'il y a de Brasses d'eau" (Fig. 11). ${ }^{31}$ These erudite notes about the Gulf also included a legend that explained that the flux and reflux of tides happens only "twice a year, on the equinoxes, on 20 or 21 March and 25 September." This quote, as Alzate comments, is taken from Bernard Forest de Belidor's Architecture hydraulique (1737, II, p. 19). Although during the course of the $18^{\text {th }}$ century cartographic representations of the oceans became progressively free from monsters and ships, the Nuevo Mapa Geográphico still contains many such depictions. The refinement and precision with which Alzate drew various types of ships, from different angles and in different locations of the Atlantic and Pacific oceans, reveal his interest in presenting technologically — and also economically — accurate information and in claiming those waters as part of the sphere of influence of New Spain.

The map's marginalia deserves some attention. Maps with figured borders were common in Dutch cartography during the $17^{\text {th }}$ century (Sáenz-López Pérez, 2014, p. 18). The origin of these decorated strips that framed the map on three or four sides is generally attributed to Willem Janszoon Blaeu (1571-1638), who appears to have been among Alzate's sources. Beyond its decorative character, Alzate's frame is an encyclopaedic display of North American plants, animals and peoples (García Rojas, 2017, pp. 14-17). The classification of natural and cultural elements (clothing, everyday objects and social

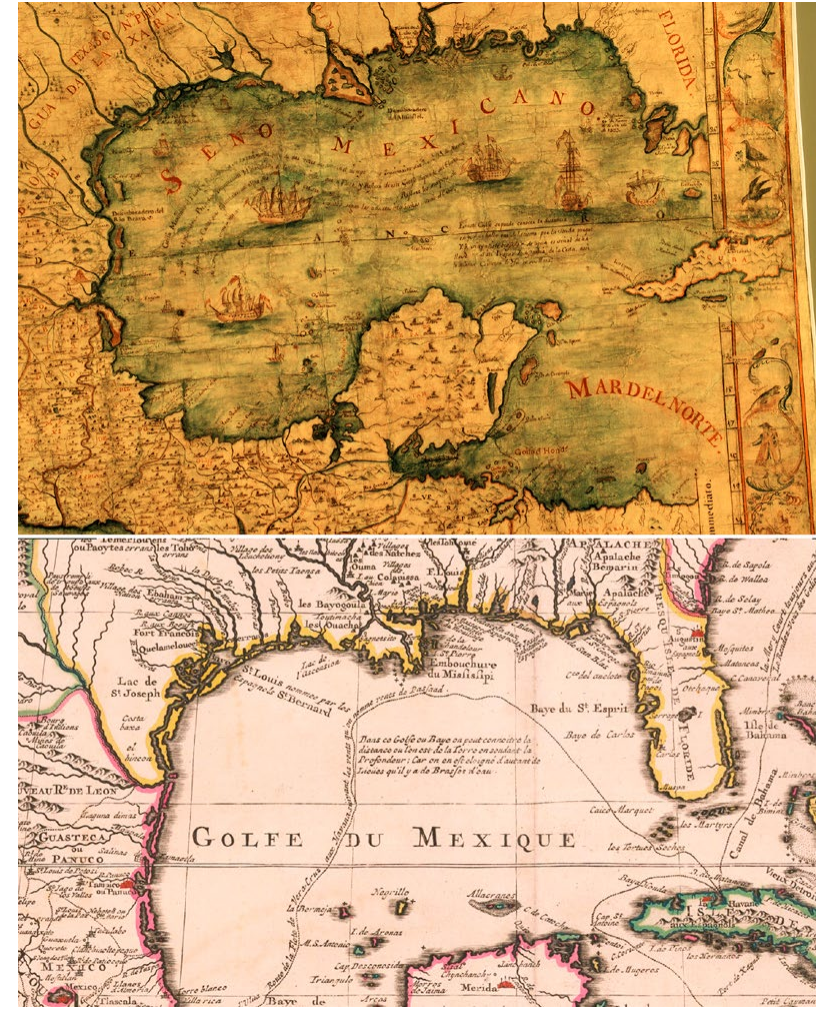

Figure i I. Gulf of Mexico in (a) Alzate, Nuevo Mapa Geográphico..., 1767, and (b) Guillaume Delisle, Carte du Mexique et de la Floride... et des Environs de la Riviere de Mississipi, 1722.

practices) evokes a new "lay taxonomy" (Bleichmar, 2012) proposed by Alzate. For him, who had impugned the use of Linnaeus's botanic taxonomy in New Spain, the natural alterity of the New World not only consisted of the existence of endemisms that were unknown to European science but also of New Spain's vernacular environmental knowledge (Moreno de los Arcos, 1989; Peset, 1987; Zamudio, 2012). According to Daniela Bleichmar (2012, pp. 151-185), the European aseptic pictorial approach to botanical representations - parts were represented separately in plates dominated by blank spaces - is altogether different from late $18^{\text {th }}$ century depictions in New Spain (like Alzate's), which do not uproot nature from its environment: fauna, flora and people are presented in specific locations, and they are colourful and exuberant.

Not all the iconographic elements are originally Alzate's. The influence of Burriel's Mapa de la California (Fig. 8) on some of the designs is clear: for instance, the "taye", or mountain ram, and the three human types from California. Alzate also used the iconography of Novus Orbis sive America Meridionalis et Septentrionalis (Matthäus Seutter, Augsburg, c. 1730) for his main cartouche: three scenes relative to the discovery and evangelisation of America, each of which included a legend in Latin (Fig. 12). To the left, three Europeans perform Columbus's egg scene, alongside the sentence Inventis facile est addere (it is easy to add what has already been discovered) and 
Alzate's note "búrlase Colón de los que apocaban el descubrimiento de la América" (Columbus mocks those who doubted the discovery of America). In the middle, there is a female allegory of the Catholic Church with a cross and a chalice, with the legend In Occidente Lux in occidua orta (in the West, light comes at sunset). Finally, to the right there are two Indians who, after depositing their jewels and arrows on the ground, kneel before an altar with Eucharistic symbols. The text in this cartouche is illegible in Alzate's version, but in Seutter's it reads Aeternas anhelat opes (riches wish for eternity).

All in all, like a "moral cartography", the Nuevo Mapa Geográphico (1767) establishes a hermeneutic pattern of how to look at the nature and peoples of New Spain, and therefore how to rule them. At first sight, this cartographic construction of American nature could be understood as a visual expression of the so-called "Creole patriotic epistemology" through which New Spain's $18^{\text {th }}$ century historians vindicated local knowledge and pointed out the flaws in foreign lines of reasoning (Cañizares-Esguerra, 2002, pp. 204-210). If we look at his later works, especially his Gazeta de Literatura, we can have little doubt that Alzate fell behind these "patriotic" postulates, which were part of the "dispute of the New World",

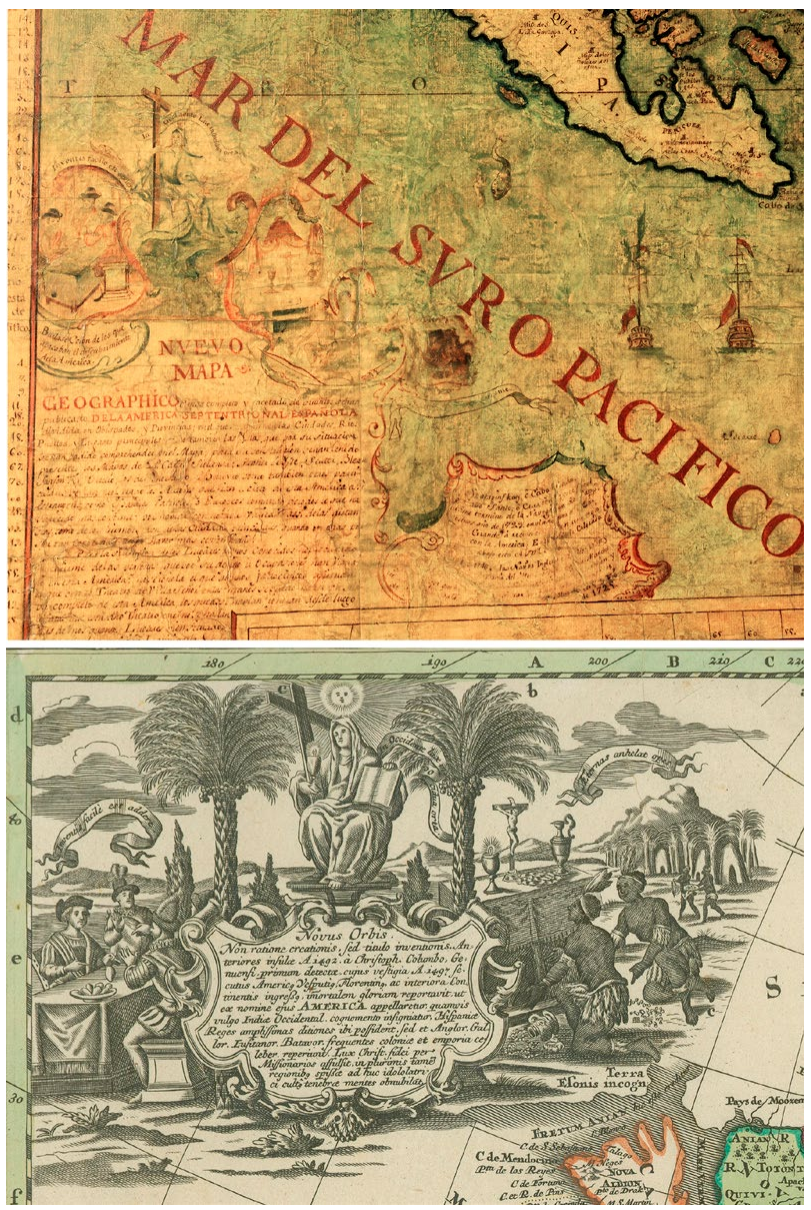

Figure I2. Allegorical scenes in (a) Alzate, Nuevo Mapa Geográphico..., 1767, and (b) Matthäus Seutter, Novus Orbis sive America Meridionalis et Septentrionalis, c. 1730. a heated debate about the inferiority of American nature and the environmental reasons behind the region's backwardness (Gerbi, 1973; Bradding, 1991). This, however, stands in stark contrast to Alzate's preference for foreign maps, the indiscriminate adoption of European iconographic models — some of them, old-fashioned by the time - and the verbatim reproduction of foreign works in his Nuevo Mapa Geográphico. If, as pointed out by Fiona Clark (2009b, p. 177), in his later years Alzate "privileged information originating in France over the Spanish domains", this "was not a process of passive adoption, but a matter of testing new ideas in the fires of the Mexican experience, disseminating what was judged valuable and fomenting discourse in a public sphere." Here, we may find the first cautious signs of this attitude: whereas Alzate did not take part in any active network of knowledge circulation - by not sending his work outside New Spain-, his cartography was little more than a disjointed collage, nearly an imitation, of well-regarded foreign works. He made maps to be admired in Mexico by people who were conversant with European visual models (some of which were, by then, fairly démodé). The value of maps - bel et utile - relied as much on appearance as it did on content. Somewhat clumsily, Alzate was beginning to display the tensions that international projection was going to bring to his work.

\section{COME-AND-GO CIRCUITS: THE NUEVO MAPA GEOGRAPHICO DE LA AMERICA SEPTENTRIO- NAL (1768)}

In the late $18^{\text {th }}$ century, the dawn of "modern geography", different models of rationality and practice, in relation to the visual representation of space, coexisted. Progressively, "non-experimental empiricism", erudite and reliant on data collection, lost ground to a mathematical model dominated by accuracy, measure and onthe-ground experience (Besse et al., 2010). In Alzate, this turn was triggered by interaction with external practices, knowledge and agents. His cartographic style refined when his work began circulating outside New Spain and he veered towards a "cartographic model" that was deemed acceptable by the international scientific community. The adoption of graphic features that adapted European models - such as the predominant use of white and the suppression of all superfluous elements - may be interpreted as a response to epistemological and aesthetic factors supported by the exactitude of mathematics and the precision of astronomical measurements (Laboulais-Lesage, 2004). If the scientific interaction of Europe and America endorsed the authority of Creole voices to explain and present the New World, the circulation of a new map - apparently simpler and more accurate — was essentially a visual argument in favour of Creole science. This new version was entitled Nuevo Mapa Geographico de la America Septentrional (Fig. 2), and was an adaptation of his 1767 map, finished by Alzate in January and February 1768 (Bret, 2001, p. 171) and dedicated to the "knowledgeable members of the Paris Académie." 32 
This transition towards a prudent "scientific asepsis" went much further than the obvious omission of some cartouches and unnecessary decoration. Alzate reframed the represented space and re-selected the coordinates of the map border: The 1767 version covered from $8^{\circ} \mathrm{N}$ to $44^{\circ} \mathrm{N}$ latitude, and from $250^{\circ}$ to $295^{\circ}$ longitude, counting from the El Hierro meridian. ${ }^{33}$ The new version goes from $13^{\circ} \mathrm{N}$ to $42^{\circ} 30^{\prime} \mathrm{N}$, and from $249^{\circ}$ to $285^{\circ}$. This new frame bypasses the controversy of the Sea of the West: at $42^{\circ} \mathrm{N}$, the "river discovered by Martín de Aguilar and Antonio Flores" is no longer regarded as a route towards this mythical sea. Most of Yucatan, Central America and the Antilles also disappear. At the eastern edge, at $281^{\circ}$, a blank space leaves out the territory of Louisiana, including the Mississippi. In this way, Alzate purged all unchecked geographical frivolities in order to satisfy the liking of the academics, but also exhibited a sensible reticence to becoming involved in controversies or being criticised for trying to represent territories that French maps were likely to represent much better. However, by omitting most references to other authors and maps, Alzate effectively presented his image of America as his own novel view.

The Nuevo Mapa Geographico de la America Septentrional was received by the Académie on 22 June 1768. It was examined by astronomer Pierre Charles Lemonnier and the geographer Philippe Buache. After comparing it "with all the maps known in France to date", the academics stressed the "great amount of new knowledge" and "characteristics that distinguish this map and make it superior to previous ones"; they recommended that the institution "ask the author for some extra accounts before it is published." ${ }^{34}$ Henceforth, Alzate started to become an internationally recognised author, and he even made it onto the list of correspondent members of the Paris Académie des Sciences between 1771 and 1786 (Bret, 2001, pp. 124-129).

In their report, Lemonnier and Buache praised the new positions and the boundary division into provinces and dioceses - "which is little known" and "is specifically colour-marked" - as well as the abundant "historical notes", for instance in the vicinity of Louisiana. They dissected some of Alzate's "old and new" sources, for instance those referring to the peninsula and Gulf of California. Some of the novelties that they highlighted were the isthmus of California, "as far as Father Wescenlao Link went in 1766" (this was one of the last contributions of the Jesuits before their expulsion) (Binková, 2007). Alzate, however, left untouched the outline of the northern Pacific coast, which was depicted "according to the only exploration of it, carried out in 16[00] by Sebastián Vizcayno." The few criticisms concerned the lack of precision of river courses, although Alzate was praised for including highly original river basins; the report argued that previous maps had erred in this regard because cartographers had given "too much credit to the reports of local savages":

All maps feature numerous [in New Mexico] tributaries of the Bravo and the Palmas, flowing into the Gulf of Mexico. Here, it is the opposite. The course of these rivers dies in lakes surrounded by land. [Similarly,] the source of these rivers [Bravo and Palmas] is not shown beyond the mountain range that runs across America [...] The same happens with a river near the town of Zacatecas, to the southeast, and which [Jean-Baptiste Bourguignon] D'Anville said was little known. In this map, this river is in fact represented as two, and according to D'Anville's one of them flows into a lake. ${ }^{35}$

The map, therefore, provided a totally different representation of the centre and northeast of New Spain, even compared to Alzate's 1767 version. The sources used for Texas, including the location of some missions and the correction of a number of coordinates, remain unidentified (Brown, 2019, p. 26). His main source was the engineer Francisco Álvarez Barreiro. Although Alzate had already used him as a source for his previous version (Codding, 1994, pp. 201-202), it is in the 1768 version that the rivers of Texas and New Mexico adopt a clear N-S direction, as determined by Álvarez in 1729. Álvarez Barreiro was the first technician to map the northern provinces based on his own observations. As a member of the frontier reconnaissance mission led by Pedro de Rivera y Villalón (1724-1728), he drew several regional maps and a general one entitled "Plano corographico é hydrographico de las provincias del Nuevo México" (Cohen, 2002, pp. 55-57) (Fig. 13). ${ }^{36}$ Alzate credited him —alongside Sigüenza and Góngora - in the cartouches of his 1775 maps and praised the quality of his work, "which is based on good material", even though "New Spain is too wide from east to west, but this is understandable, for the terrain is bad, the roads tortuous, and observations of longitude, few." ${ }^{37}$

Despite his technical profile, Álvarez Barreiro reproduced local geographies that other authors had dismissed as mythical. Nahuatl traditions referred to Aztlan as the ancestral origin of the Aztec people, and whence the first inhabitants of Mexico had departed. Evoking its alleged position and its relationship with a lake, Álvarez placed the point of departure of the mythical migration on the northwestern edges of his map (Fig. 13), at "Teguayón Lake or Estero Azul, the place whence Mexican Indians departed with their Prince to populate Mexico", a reference that Alzate adopted from 1767 onwards. Without

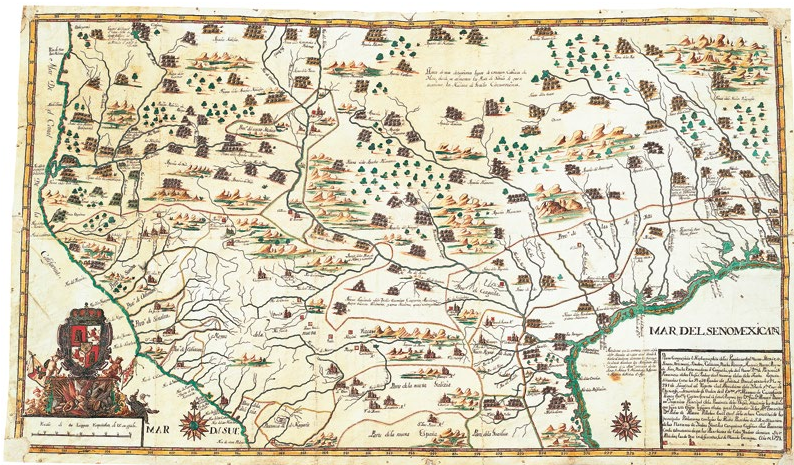

Figure I3. Álvarez Barreiro, Plano Corographico e Hidrographico de las Provincias del Nuevo Mexico, 1729. Facsimile, original in the Hispanic Society of America, New York. 
drawing the whole route, Álvarez Barreiro mentioned three stops in the peregrination that led to the foundation of Mexico-Tenochtitlan, which Alzate also copied (Fig. 14). He placed the "Mexican Indian's first mansion" in the confluence of the Verde and Azul Rivers - the latter was omitted by Alzate-; the second to the south of the Gila River, and the third to the southeast, near the boundaries of Nueva Vizcaya. This legendary geography not only made it onto Alzate's printed maps, but also the cartography of New Spain published by Humboldt beginning in 1803 (Rodríguez, 2014, pp. 49, 94). Other original texts by Álvarez Barreiro are also present in Alzate's and Humboldt's work, such as the "plains, over 300 leagues long, covered in hay, where Cíbola cattle graze, which sustain the nearby nations of gentiles", located in the large blank space at the centre of the top of the map.

Awaiting Alzate's response, a few days after Buache and Lemonnier's report was read, the secretary of the Académie Jean Defouchy gave orders for Alzate's map to be adhered to a fabric and filed. The print version was to be based on a copy made by the Premier Géographe du Roi. In summer 1768, Philippe Buache and his assistants made several copies of Nuevo Mapa Geográphico. One of them was made for Abbé Chappe d'Auteroche, who wished to take it on his trip to Mexico (Bret, 2001, pp. 172-173). This was the "copy of the Map of this Kingdom" that

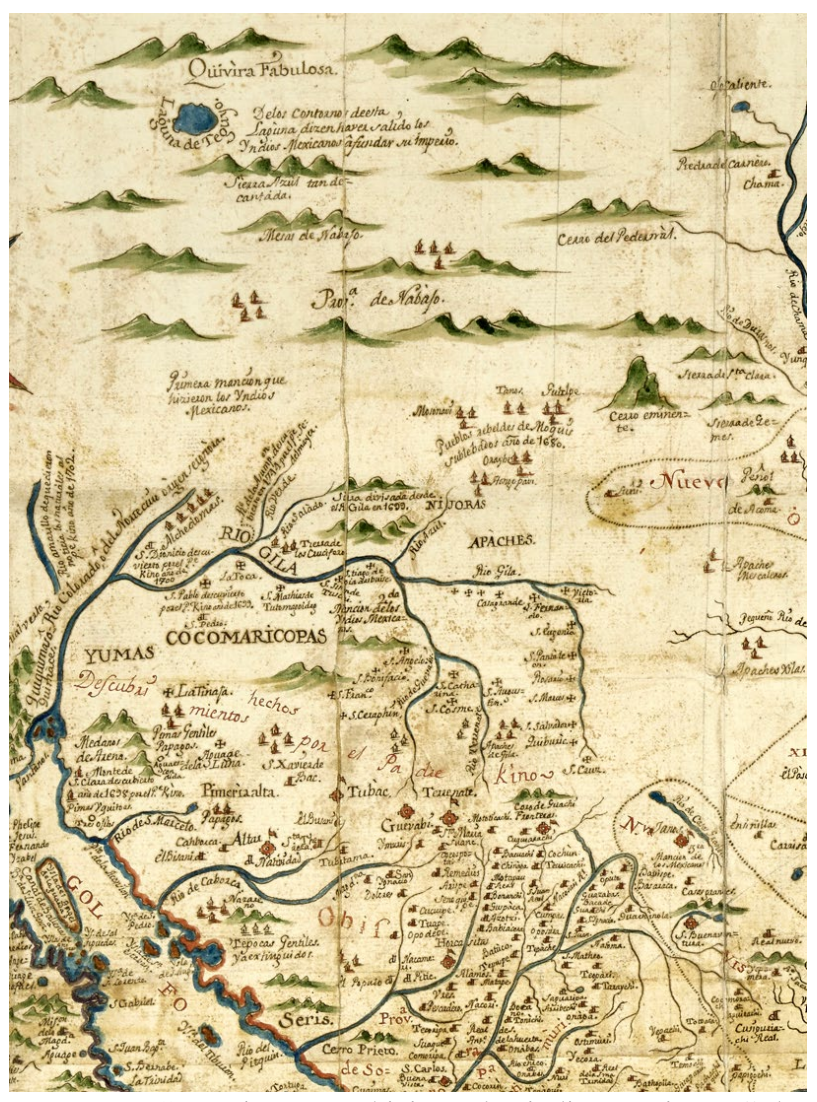

FigURE I4. "Mansiones que hicieron los indios mexicanos" detail in Alzate, Nuevo Mapa Geographico de la America Septentrional..., 1768. Bibliothèque d'Institut de France, Paris. Reproduced with permission.
Alzate saw in the Abbé's hands during their meeting in March $1769 .{ }^{38}$ A second manuscript copy, currently kept in the French National Library (Fig. 15), ${ }^{39}$ comes with an attached tracing of the cartouche that featured on the map given to Chappe d'Auteroche, which confirms the official nature of the copy and the authorisation, signed by the secretary of the Académie, for the astronomer to take it with him to New Spain (see Fig 17b).

I suspect that the map carried by Chappe d'Auteroche could be the one preserved in the Beinecke Rare Book \& Manuscript Library, at Yale University (Fig. 16). ${ }^{40}$ The cartouche of this map (Fig. 17a) seems to be the model followed in the mentioned tracing (Fig. 17b), with the authorisation and handwritten signature of the Grand Jean Defouchy and the stamp of the Library of the Académie des Sciences. The map shows some signs of usage and is therefore damaged in the paper folds. In the southernmost part of the Gulf of California, some handwritten notes with observations and alternative coast contours were added (Fig. 18).

The academics's positive opinion, and seeing a copy of his map in the hands of Chappe d'Auteroche, greatly contributed to softening Alzate's invectives against foreign authors, especially Buache. Seeing himself as the last link in a chain, and not wishing "to mock wise men", Alzate described the advancement of knowledge as "the most recent author always replacing" the earlier ones. His criticism was finally framed as praise: "Has the memory of M. Isle, who was in his time considered the world's top geographer, not become more obscure compared to the Buaches, Robertos, Ambilles, Bellines and others?"41

Following the interests of the academics, the two known copies outline river courses more precisely, and river basins flowing into both oceans are marked by subtle shading (see Fig. 18). Although this hydrological study did not reach the printed version, the exercise helped to articulate and correct to the west the position of Sierra Madre. Alzate had begun by conventionally drawing the mountains pictorially as they might be seen from a lateral perspective from above (Harvey, 1980, pp. 182-183), thereby evading the need to represent the range accurately. It is likely that a third copy of the map was made as a model for the printing press. It is possible that this version already presented the differences in decoration and text noticed by Wesley Brown (2019, p. 25).

The publication of Alzate's maps began once Jean Pauly, assistant of the deceased Chappe d'Auteroche, brought Alzate's additional notes to Paris. In January 1772, Jean Nicolas Buache de la Neuville presented before the Académie two print proofs produced under the supervision of his uncle, Philippe Buache. In the new design, the frame of the map was adjusted by a few degrees, the map scale was reduced by one quarter and the paper size by three quarters. Once Buache knew the recent astronomical observations by Chappe d'Auteroche brought by Pauly, he wondered whether "an annotation [with the corrected geographical coordinates] should have been added." In the end, however, it was decided to leave the coordinates as Alzate originally had depicted them. The 


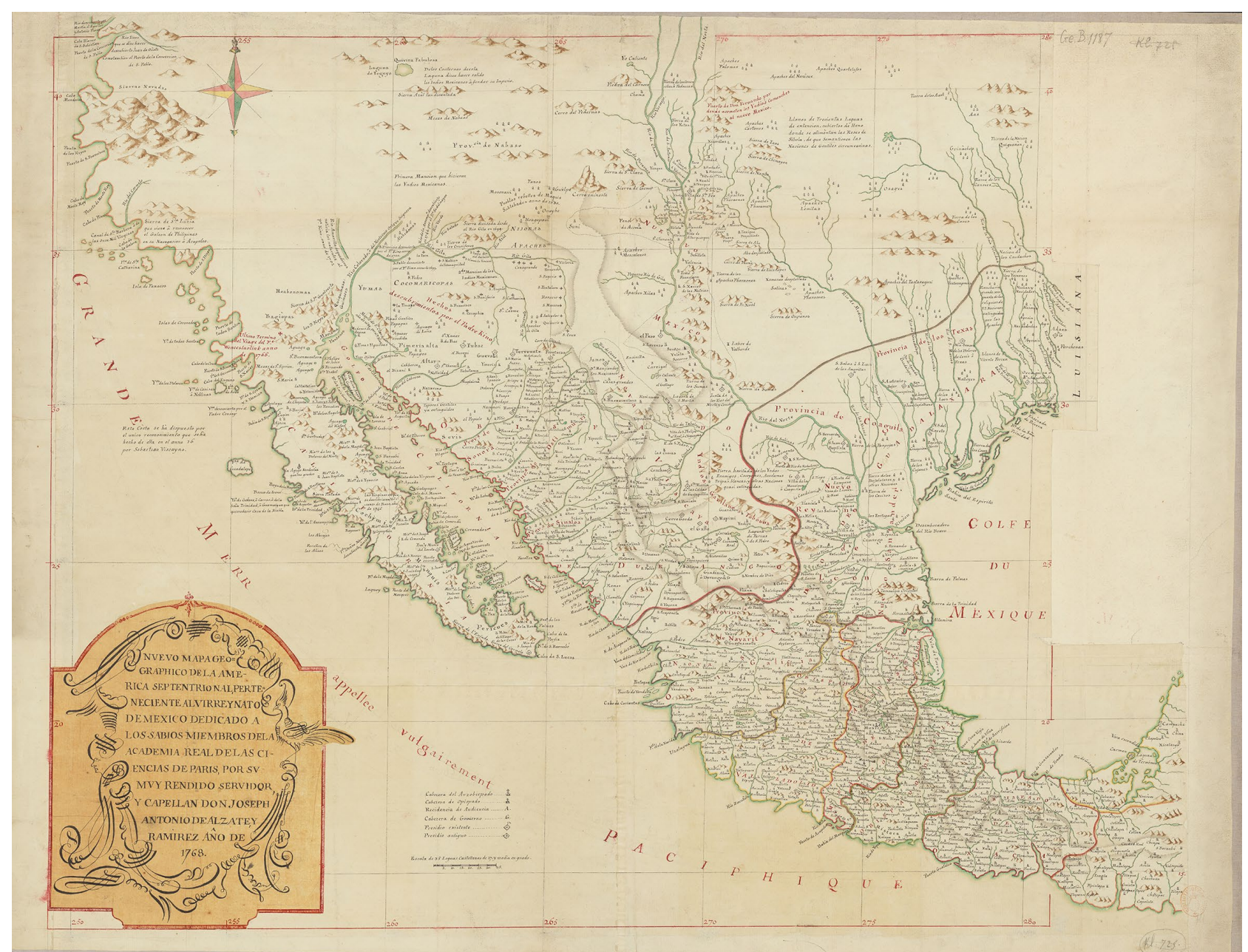

Figure I5. Philippe Buache's manuscript copy (1768) of Alzate's Nuevo Mapa Geographico de la America Septentrional, perteneciente al virreynato de Mexico, 1768. Courtesy of the Bibliothèque Nationale de France, Paris.

astronomers Pierre Charles Lemonnier and Jean Dominique Cassini, who saw the proofs, decried Buache's doubts, and told him that he should have put all the places at the correct coordinates. At that point, although they would endorse the publication of the map sous le privilége de l'Académie, there was little choice but to include "a cartouche to add the corrections that there was no time to implement." ${ }^{42}$ In this context, both astronomers raised the question of authorship and the role of the Académie as editor and producer of good-quality and useful cartographic instruments:

Would it not have been better, more natural, to use those corrections instead of putting Veracruz, Mexico and San José [del Cabo] in a position that we know to be wrong, and which we shall need to correct in an annotation? This would not, in truth, be the map that Alzate sent to the Académie, but we must ensure that it is as exact as possible, a map that the Académie itself can use everywhere, with corrections implemented by one of its members. Otherwise, the Académie is no longer José Antonio de Alzate's editor. ${ }^{43}$
Therefore, next to the title cartouche, which was in Spanish and bore the date "1768", the Buaches added a table in French amending the old coordinates: "After this map was made, M. Chappe's voyage to California allowed for the correction of the position of various places [...] Longitude is counted from the El Hierro meridian" (Fig. 19). However, they made a mistake when engraving the longitude of Veracruz. The French National Library has several printed copies of Nuevo Mapa Geographico de la America Septentrional with the amended table pasted on it and the manuscript note: "correction to be implemented upon the Spanish map of Mexico for the longitude of Nueva Vera Cruz, which must be $282^{\circ}$ instead of $285^{\circ}$." In other copies, however, the wrong figure was scratched out, and a 2 was written over the 5 (Fig. 20). ${ }^{44}$ Although most of the maps in circulation were the corrected version, a few which had not been amended could also be found. Humboldt, who compared the deviations of the Alzate's map and the positions given by Chappe d'Auteroche in his Carte des fausses positions, ${ }^{45}$ pointed out the typographical mistake in the cartouche of Nuevo Mapa Geographico (Humboldt, 1811b, II, p. 862). 


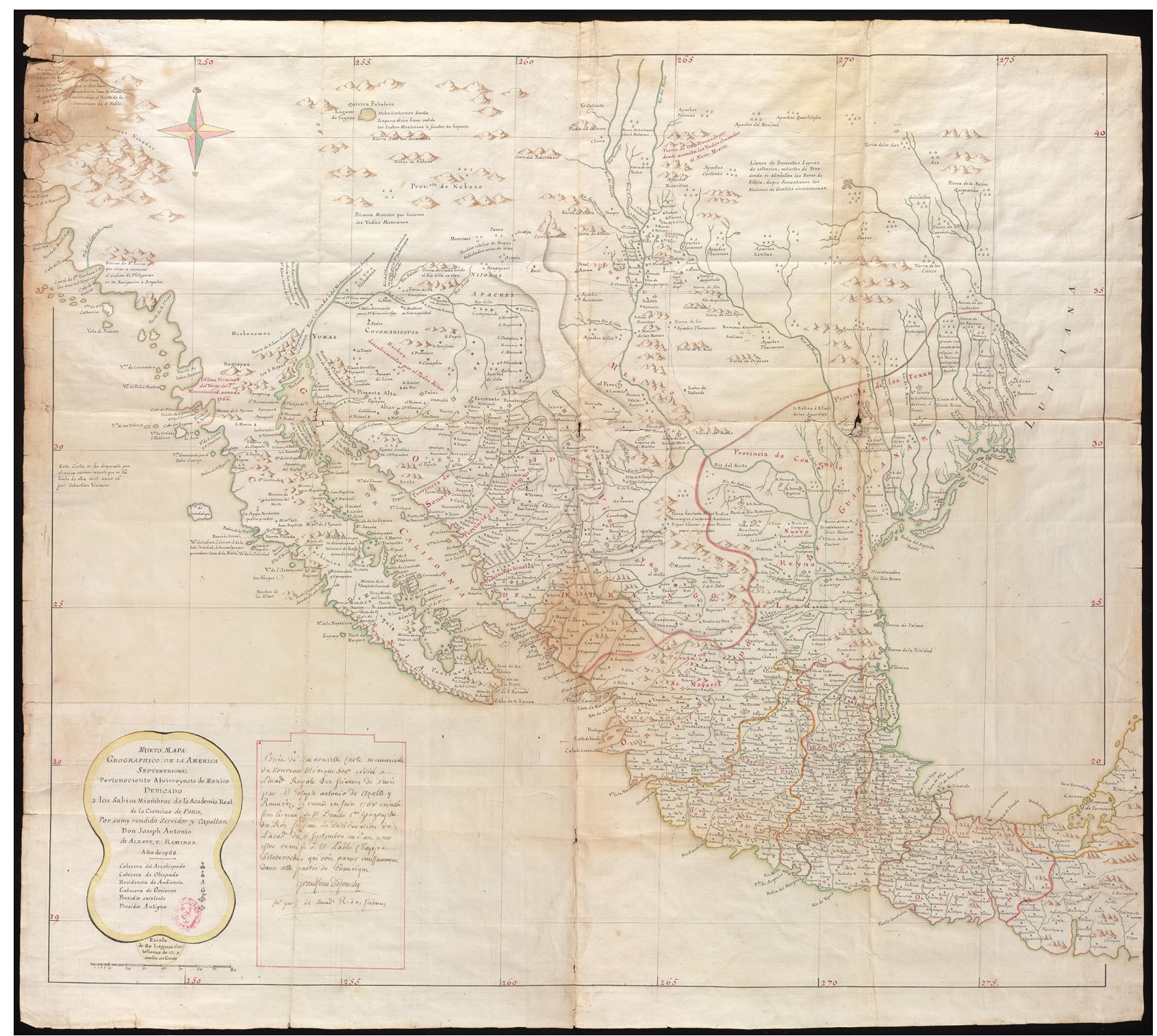

Figure i6. Philippe Buache's manuscript copy (1768) of Alzate's Nuevo Mapa Geographico de la America Septentrional, perteneciente al virreynato de Mexico, 1768, signed by Jean Defouchy. Courtesy of the Beinecke Rare Book and Manuscript Library, Yale University, New Haven.

After the death of Philippe Buache in 1773, his plates and instruments were left to his nephew, Jean Nicolas Buache de la Neuville, who carried on printing until his death in 1780 . His printing materials were bought by the prolific French editor and engraver Jean Claude Dezauche (Petto, 2007, p. 183), some of whose copies of Alzate's maps are known. These new maps included a corrected version of the coordinates table and a printing mark at the bottom of the page which read: "In Paris, by Dezauche, engraver, heir and owner of Delisle and Buache's geographical collection" (Fig. 21). ${ }^{46}$

Two more editions of the Nuevo Mapa Geográfico, fully in Spanish, came out. In contrast to the French editions, which were engraved on a single plate, the Spanish editions were engraved on four. Since it was re-engraved, some profiles were perfected and types were changed, spelling mistakes were corrected, and some notes were rewritten (Brown, 2019, p. 24), but no changes were introduced in the geographical design to update the coordinates. The frame of the cartouche was removed and the Académie's privilege was translated into Spanish, as was the amendment table, but without crediting Chappe d'Auteroche's expedition (Fig. 22). ${ }^{47}$

It is likely that these editions were printed in Madrid by the prestigious Spanish geographer Tomás López de Vargas y Machuca (1731-1802), who was trained in Paris between 1752 and 1760 , but only one of them bears López's printer's mark. They are difficult to date precisely, but they must be dated to after 1790 . None of the versions of Nuevo Mapa Geográfico feature in the collection 

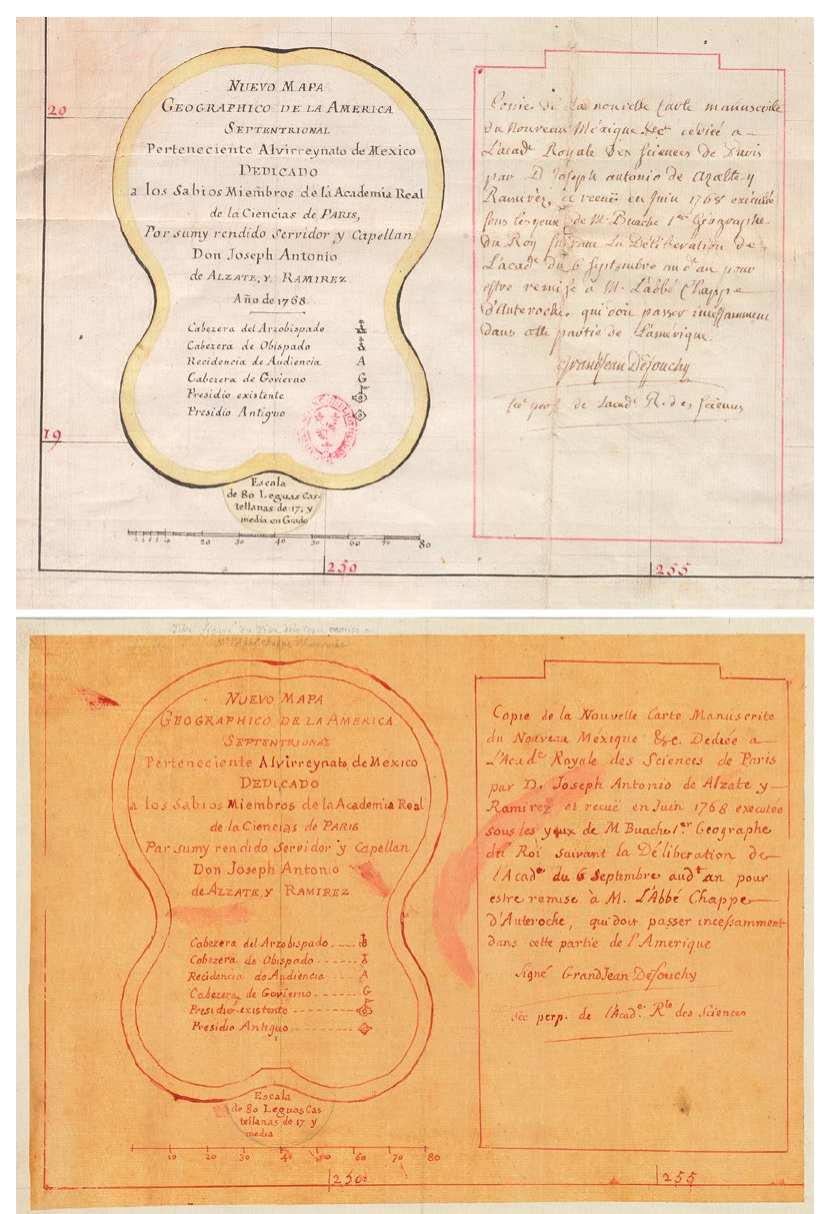

FIgure I7. (a) Cartouche detail and Defouchy's signature in Buache's copy of Alzate's Nuevo Mapa Geographico..., 1768 (Beinecke Rare Book and Manuscript Library, Yale University). (b) Tracing of the prior cartouche attached to Buache's copy of Alzate's Nuevo Mapa Geographico..., 1768 (Bibliothèque Nationale de France).

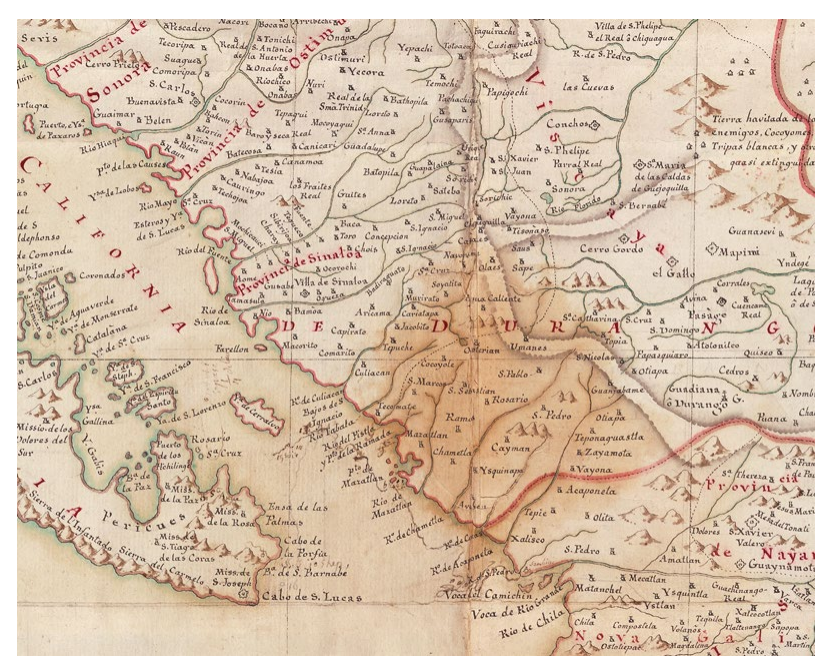

Figure I8. Handwritten notes in the Gulf of California and Sierra Madre details in Buache's copy of Alzate's Nuevo Mapa Geographico..., 1768. Beinecke Rare Book and Manuscript Library, Yale University.
Mapas de América, pertenecientes a la Real Academia de la Historia, finished by Tomás López in 1790. The collection includes his own maps as well as some made by others, the latest of which is dated to 1787 . The collection, however, included a manuscript copy of Domingo del Castillo's above-noted map, which was publicised by Alzate (López and Manso, 2006, pp. 79-82). The printer's mark refers to the place to which Tomás López and his sons Juan and Tomás Mauricio moved their workshop in 1783: "In Madrid, Calle de Atocha, opposite the Guild's house" (Fig. 23). ${ }^{48}$ However, although they began including their printer's mark on their products from this same year, the exact wording that appears on the map was not used until 1792, and underwent no major changes until at least 1801 (Codding, 1994, p. 199; López Gómez, 2000, pp. 385-384).

In Spain, Alzate's map caused an immediate stir in erudite and Francophile circles. In 1792, the editors of the Spanish version of the Encyclopédie méthodique added several new entries to the volume of Geografía Moderna (originally published in Paris between 1783 and 1788, and coordinated by Diderot), where Alzate's map became a source of accurate information: the entry that dealt with the limits of the Nuevo Reino de León compelled the reader to see "the map of Mexico's viceroyalty, drawn in Mexico in 1768 by the priest and erudite D. Joseph Antonio de Alzate [...] and published by the Academy of Sciences of Paris." The map was also mentioned in the entries for the Nasas and Nayarit Rivers, where it was compared to Diccionario geográfico-histórico de las Indias Occidentales o América produced by the military academic Antonio de Alcedo (Arribas and Velasco, 1792, II, p. 563; III, pp. 246, 255). According to Juan López's catalogue (Juan was the son and heir of Tomás), the map was still on sale in 1808, and the price was 14 reales (Hernando Rico, 2008, p. 173). By then, however, Alzate's cartography must have become obsolete because Juan López did not use it as a model for his maps and atlases of North America.

\section{CIRCULATION AND CONSOLIDATION OF A CARTOGRAPHIC MODEL: THE PLANO GEO- GRAFICO DE LA MAYOR PARTE DE LA AMÉRICA SEPTENTRIONAL ESPAÑOLA (1775)}

José Antonio de Alzate remained oblivious to the editorial vicissitudes his cartography was subject to in Europe. He also was unaware of his appointment as a correspondent member of the Académie until 1775, at the earliest, and the map which "was published by the famous geographer Buache in 1775 [sic] under the initiative of said academy" did not reach his hands - supposedlyuntil 1792. According to Alzate, the map's arrival in New Spain was made possible thanks to the "patriotic zeal and love" of the merchant Diego de Agreda Martínez de Tejada, who requested "fifty copies, which he gave to people who could make use of it in their business." ${ }^{\prime 9}$ In the meantime, Alzate continued reflecting on his activity as a geographer, making astronomical observations and correcting and updating his maps. 


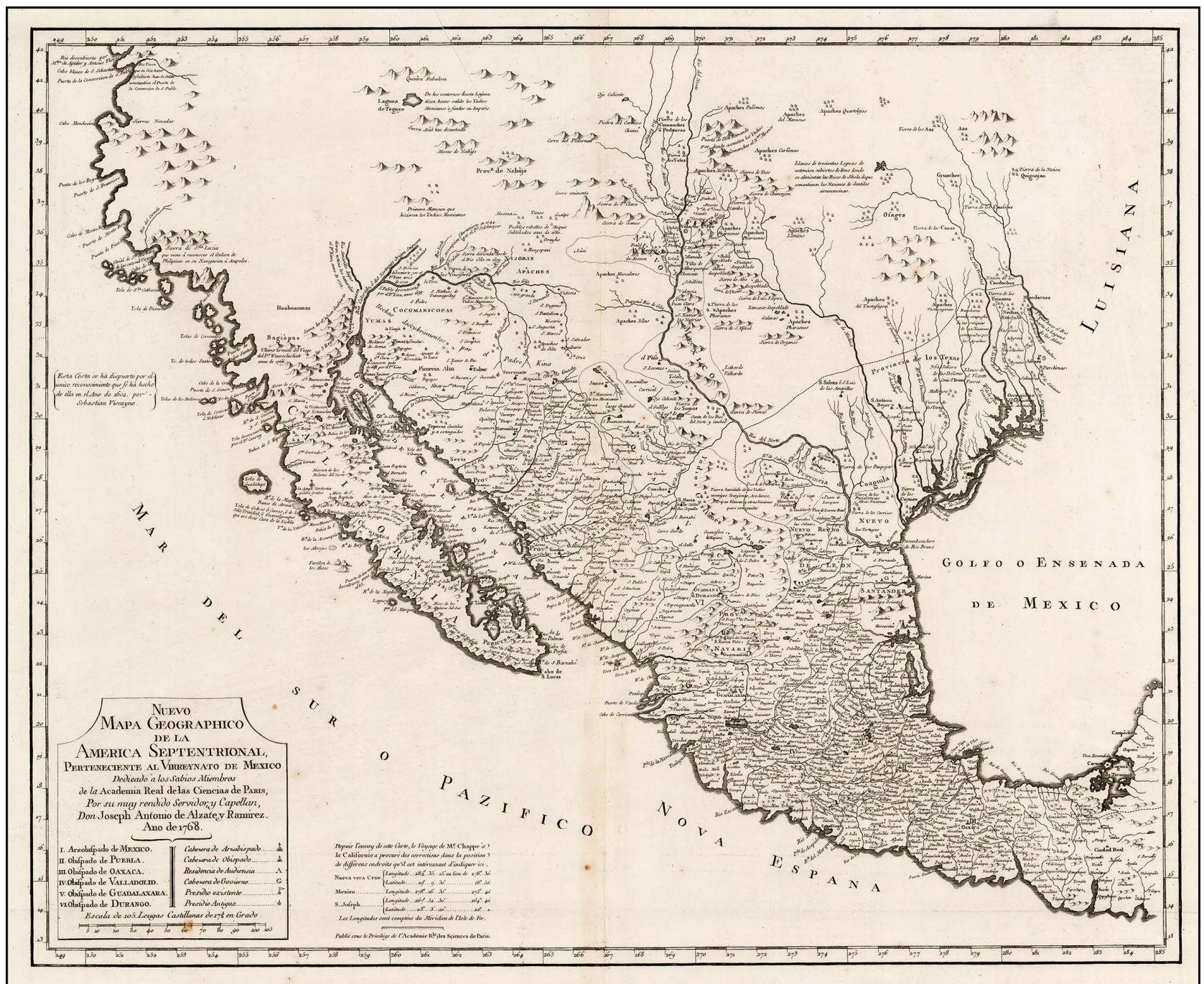

FiguRE I9. Académie Royale des Sciences’ printed version of Alzate's Nuevo mapa geographico de la America septentrional, perteneciente al virreynato de Mexico, dedicado a los sabios miembros de la Academia real de las ciencias de Paris por... Joseph Antonio de Alzate y Ramirez. Año de 1768 (Paris, 1772). The Barry Lawrence Ruderman Map Collection courtesy Stanford University Libraries.

On 7 December 1772, he printed the essay "Estado de la Geografía", in which he explained the importance of the recent observations of the transit of Venus and the satellites of Jupiter he and Joaquín Velázquez de León had carried out, and "which give an accurate measure of longitudes" of Mexico. ${ }^{50}$ The reference to this astronomer triggered a bitter controversy as to who had calculated the position of the capital first (Moreno de los Arcos, 1977, pp. 143-146). Velázquez argued that Alzate "cannot display any geographical chart earlier than mine which shows Mexico and New Spain in their correct place." He was referring to a "map of the provinces of Nueva Galicia, Nueva Vizcaya, Sinaloa, Sonora and California" which he made "as commissioned by the government on 15 November 1772" (Velázquez, 1775, p. 206). Even Alzate had mentioned this map in his articles: "Not long ago, D. Joaquín de Velázquez finished [a map of] this part of New Spain, which is very good in general, and his coordinates exact." ${ }^{51}$ In the cartouche of this map, now lost, Velázquez noted that, after his observations and those of others, he had "the honest pleasure of believing that this [was] the first geographical piece to present these places at those coordinates where Providence had put them" (Velázquez, 1775, pp. 206-207).

In the context of this controversy, it is interesting to examine the Plano de las Provincias de Ostimuri, Sinaloa, Sonora y demás circunvecinas y parte de California, signed by Alzate in 1772, in which the peninsula's outline was placed in the new positions (Fig. 24). ${ }^{52}$ The Plano de las Provincias... is circumscribed to between $22^{\circ}$ and $42^{\circ} \mathrm{N}$, and $261^{\circ}$ and $275^{\circ}$ longitude, and covered such a small area because it focused on emphasising the correct location of certain locations. It follows the synthetic approach adopted by Alzate in 1768 in his general maps, and uses the same icons, scale, legends and colours. As a novelty, San José del Cabo is at $269^{\circ}$, more than four degrees to the east of the position expressed in the map sent to the Académie (originally at $264^{\circ} 40^{\prime}$, position that was 


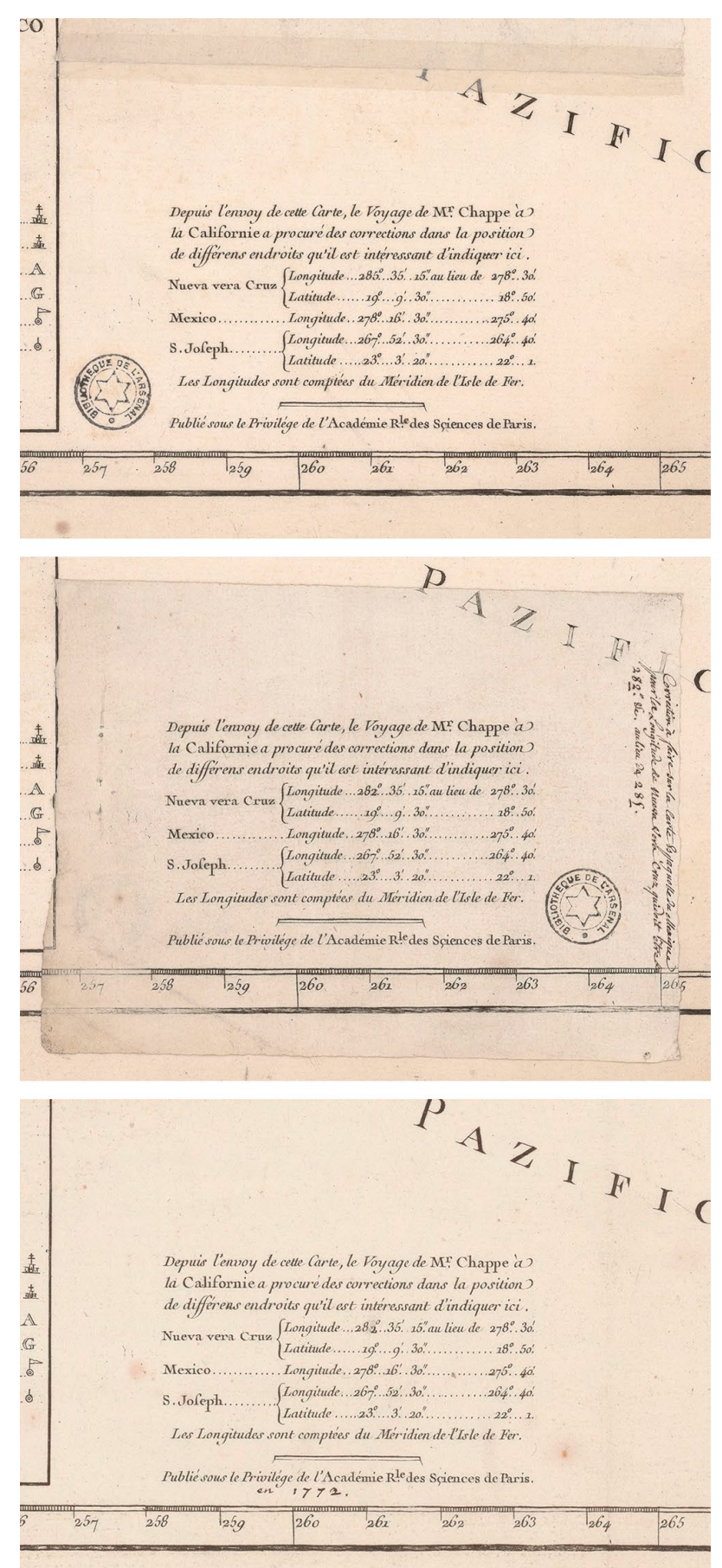

FIGURE 20. (a) Erroneous cartouche and (b) the patch with the amended table pasted on Académie, Nuevo mapa geographico... (1772) BNF, département Arsenal, EST-1504 (13). (c) Figure scratched out and overwritten in BNF, Cartes et plans, GE C-10971. Courtesy of the Bibliothèque Nationale de France, Paris.

corrected in the annotation of the French printed version to $\left.267^{\circ} 52^{\prime} 30^{\prime \prime}\right)$.

Alzate, however, did not mention this Plano in his "Estado de la Geografía" (1772), even though this work reviewed the most recent cartographic sources for the

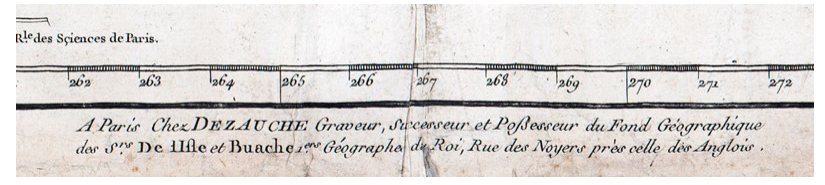

FIGURE 2 I. Dezauche's printing mark on his version of Alzate's Nuevo mapa geographico de la America Septentrional, after 1780. Courtesy of the Texas Collection, Baylor University, Waco, Texas.

northwest. It is likely that he finished it after the publication, in late 1772, but he gives no precise date. Given his conflict with Velázquez de León, we may surmise that the date in the Plano does not in fact correspond to the actual date when he made the map but is a generic reference with which, soon afterwards, Alzate tried to claim precedence over the astronomer. In 1770, Alzate claimed to the French academics that he had already begun making some corrections to his cartography of New Spain: "having taken away much of the width that is conventionally given from east to west, according to the observations of the transit of Venus here [Mexico City] and in California, in order to assign to it its proper size.. ${ }^{53}$ However, he did not use this date (1770) to address the public of New Spain, which his detractors would have flagged out as too early. In addition, he had no known maps attributed to him to prove it.

In two later maps, both dated to 1775 , Alzate claimed to have made these changes in 1772 based on astronomical observations undertaken in "Cape San Lucas by the astronomers who came to observe the transit of Venus sit and, soon afterwards, by Don Joaquín Velázquez; in Mexico, by myself, and later by said Don Joaquín de Velázquez; and finally in Veracruz, by Don Vicente Doz", which was a way of pointing out that he had pre-empted the astronomer. These 1775 maps, which are kept in the Museo Naval in Madrid (Fig. 25) and the British Library (Fig. 26), ${ }^{54}$ feature new coordinates for North America. The northeast of the continent, which had previously been presented as a wide blank area full of cartouches and mythical cities, is now narrower: "On the maps it was westerly by four and a half degrees, so voyages coming from Europe to New Spain were longer than reckoned, while those coming from the Philippines were shorter."55 Based on these designs, we can explain the new mechanisms of cartographic circulation in which Alzate participated, as well as the devices of consolidation and display of a pretended "astronomical turn."

The Plano Geografico de la mayor parte de la América Septentrional Española (Cartographic map of most of Spanish North America) (Fig. 25) was presented in 1940, soon after its purchase by the Museo Naval in Madrid (Guillén, 1940, p. 197). The map, signed by Alzate on 22 October 1775, has the same style, scale and aseptic appearance as the one he sent to France. However, perhaps because it was directed towards a different audience, Alzate recovered previously omitted geographical features: from the map he had dedicated to Lorenzana (Fig. 5), he rescued the mythical Sea of the West, and, 


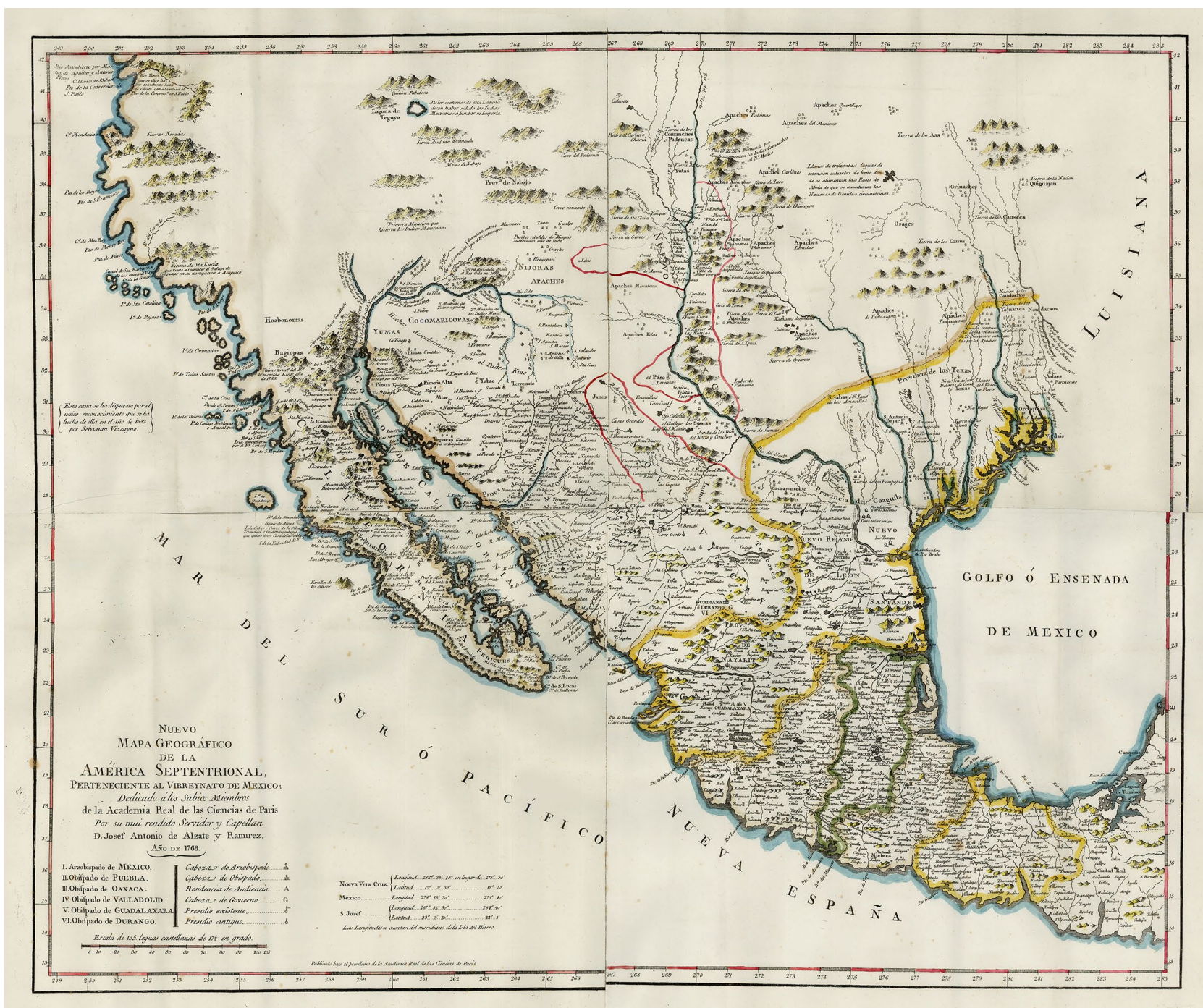

Figure 22. Spanish version of Alzate's Nuevo Mapa geográfico de la América Septentrional, after 1790. The Barry Lawrence Ruderman Map Collection courtesy Stanford University Libraries.

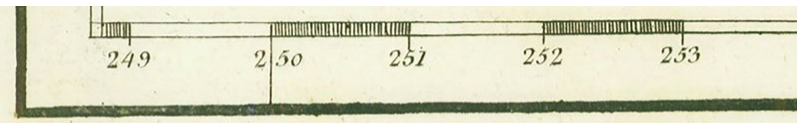

Se hallarié en Madid, calle de Atocha, frente la casa de los Gremios.

Figure 23. Tomás López's printing mark on his version of Alzate's Nuevo Mapa geográfico de la América Septentrional, after 1792. Beinecke Rare Book and Manuscript Library, Yale University.

following new sources, he again included the territories of Louisiana, Florida, the Antilles and Central America as far as Honduras and Nicaragua. It covers from $9^{\circ} \mathrm{N}$ to $45^{\circ} \mathrm{N}$, and from $255^{\circ}$ to $300^{\circ}$ longitude. The copy in the British Library (Fig. 26) belonged to a collection in the British Museum, which bought it in 1848 (Bond, 1868, p. 41). It is almost identical to the one in Madrid, except for the fact that it covers a slightly smaller surface (from $11^{\circ} \mathrm{N}$ to $44^{\circ} \mathrm{N}$, and from $255^{\circ}$ to $299^{\circ}$ longitude). It bears the same title, which is framed by a Baroque garland, and is dated to 14 November 1775 . In the explanatory text, besides claiming that its source is a prototype from 1767 , amended by the author in 1772, the references are mentioned: "the best written and verbal reports, as could be found, as well as some manuscript maps (no valuable printed ones exist), especially those by Don Carlos de Sigüenza and engineer Barreiro." For the first time, Alzate exhibits in these two maps his credentials as a member of the Académie and the Sociedad Bascongada.

Comparing the 1772 (Fig. 24) and 1775 maps (Figs. 25 and 26), some differences can be appreciated in some locations and toponymies on the western coast and the California peninsula. The conflicted profile of this geographical area indicates the evolution of the author's scientific practice. Earlier, Alzate had argued for its originality and novelty, and thus justified the discrepancy between his innovative work and earlier sources. In 1770, Alzate explained the differences between his cartography and Gaspar de Portolá's observations in 1768-1770 con- 


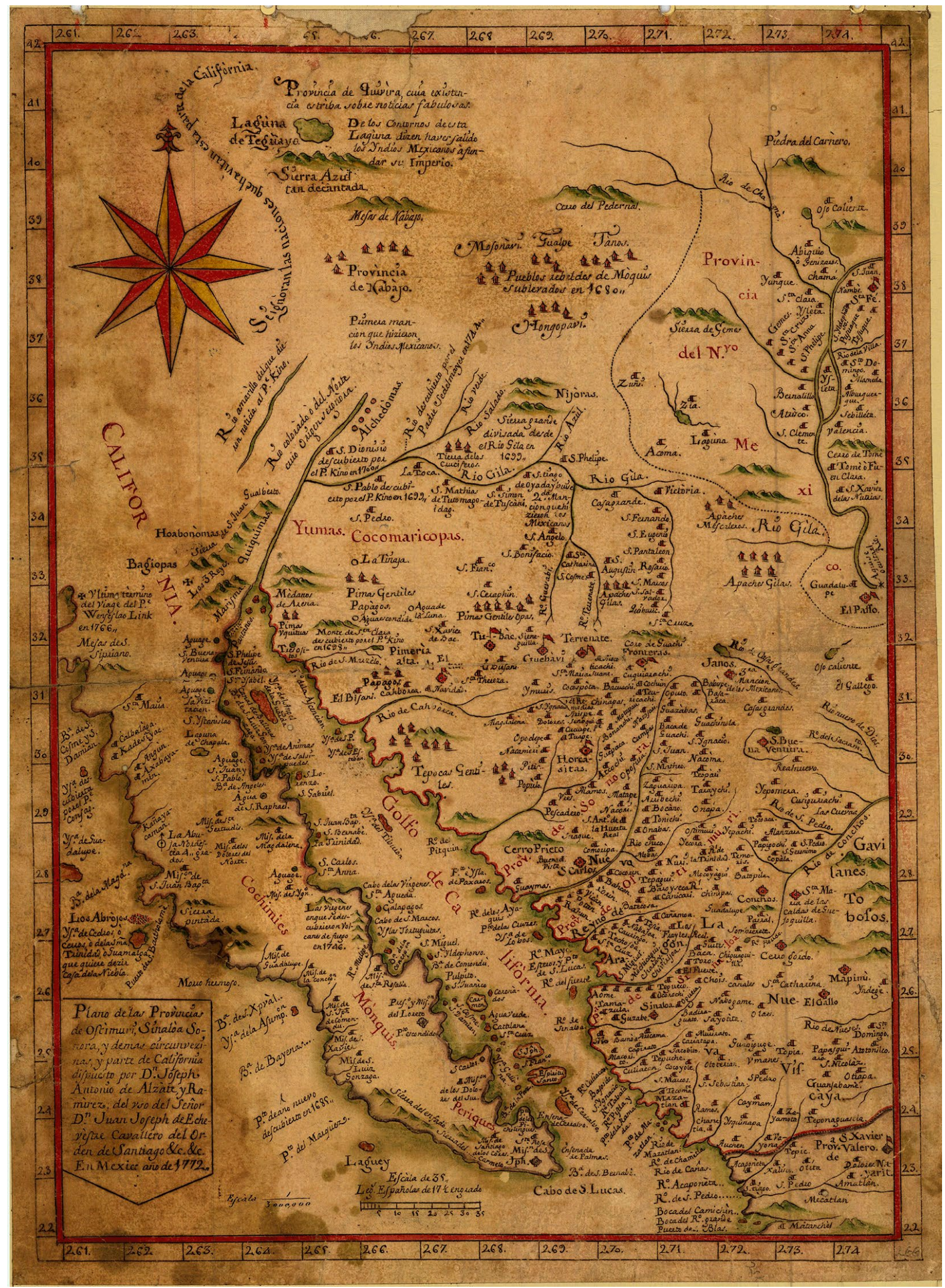

Figure 24. Alzate, Plano de las Provincias de Ostimuri, Sinaloa, Sonora y demás circunvecinas y parte de California, c. 1772. Courtesy of the Mapoteca Manuel Orozco y Berra, Ciudad de México. 


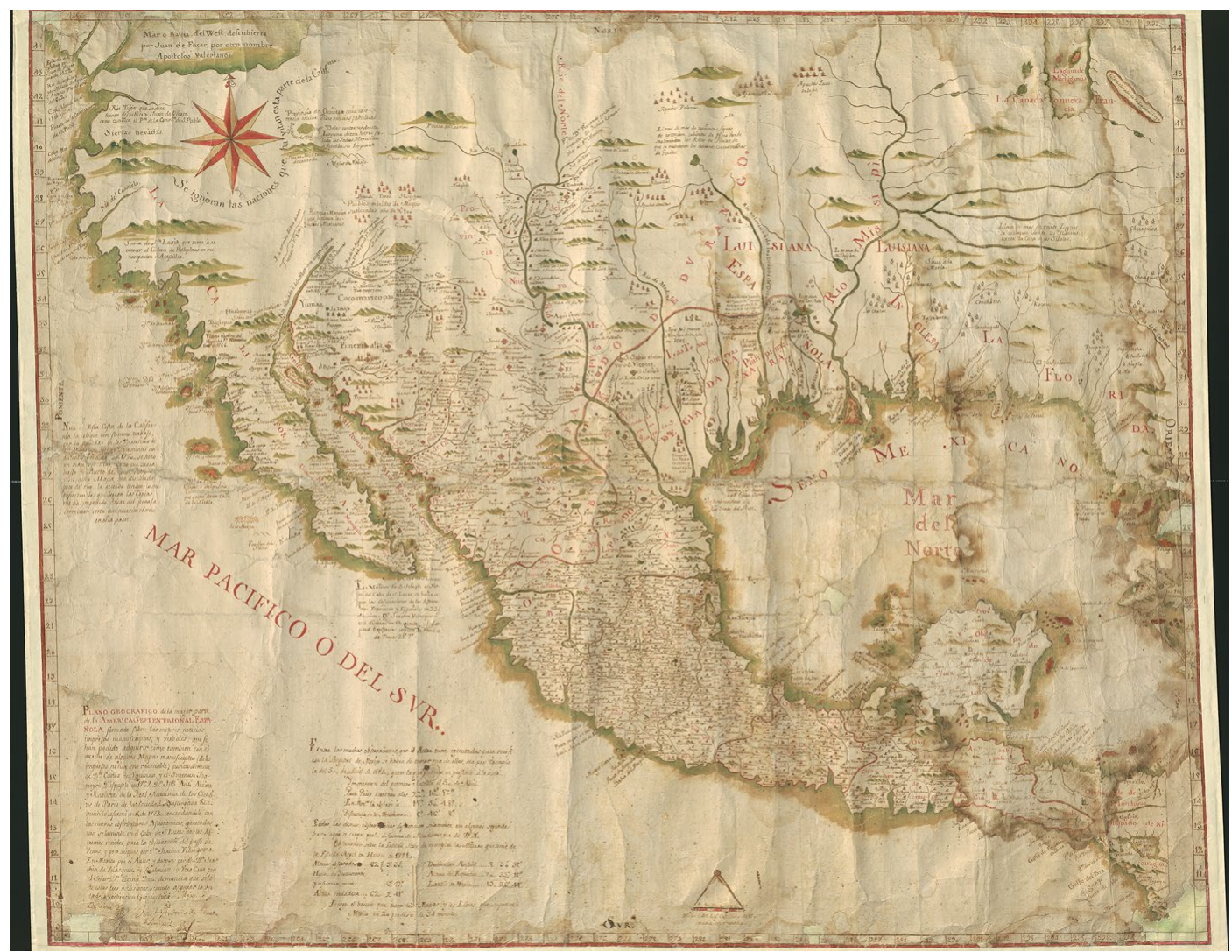

Figure 25. Alzate, Plano geografico de la mayor parte de la America Septentrional Española, 1775. Museo Naval, Madrid. Reproduced with permission.

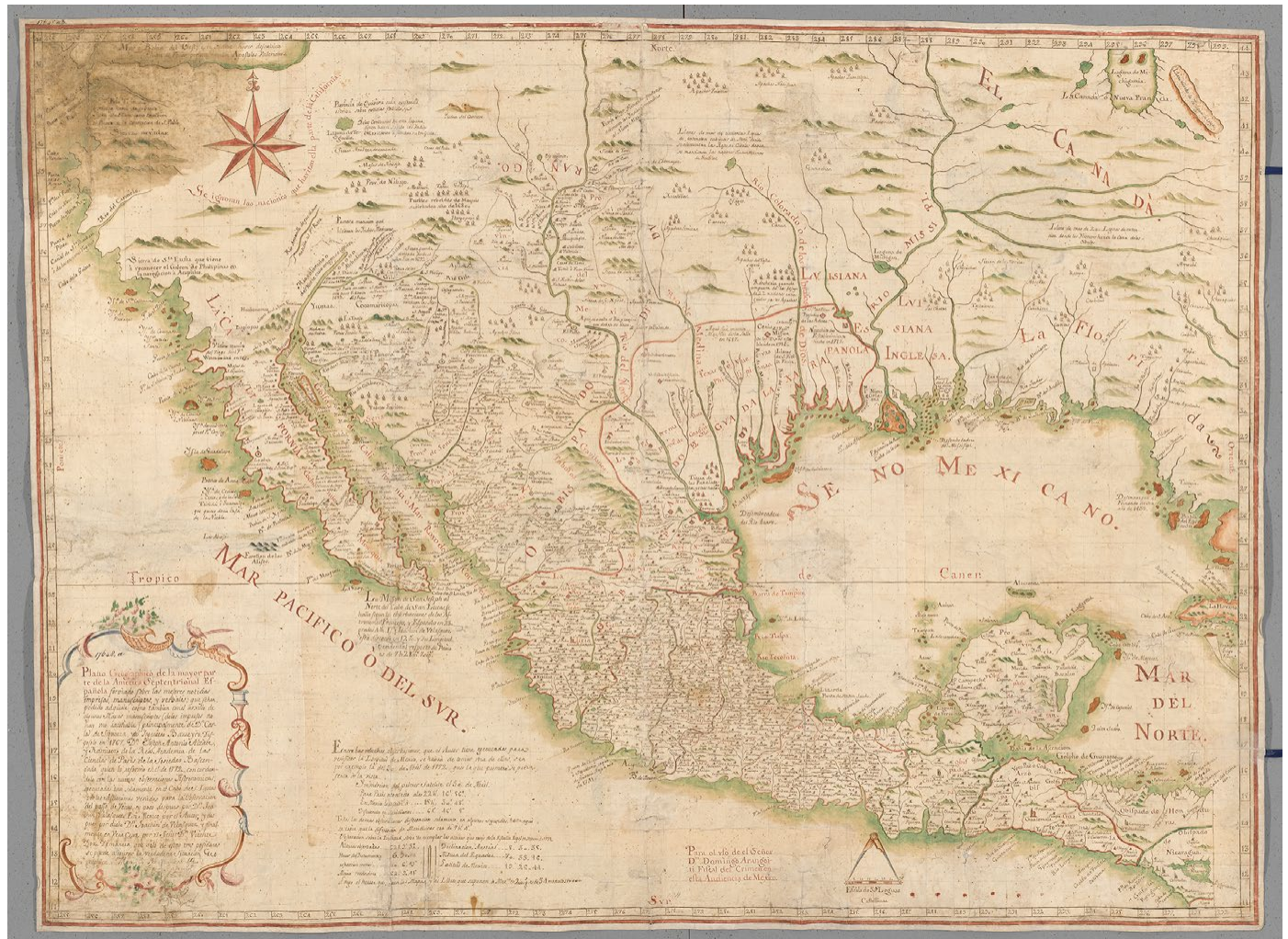

Figure 26. Alzate, Plano geografico de la mayor parte de la America Septentrional Española, 1775. British Library, London. Reproduced with permission. 
cerning Alta California: "Last year, an expedition undertook the measurement of the Californian coast up to Cape Mendocino, and the resulting map is no different to mine, except that the peninsula is not narrowed between 23 and 32 degrees, like in mine." However, based on Wenceslao Link's observations, he challenged the results of the Crown's engineers, including Miguel Constanzó, by drawing a narrower California: "but I have in my power a missionary's report, made during an overland trip, and I am inclined for the narrower distance." ${ }^{56}$ Five years later, Alzate had abandoned this discourse, and the copy in the Museo Naval makes reference to the multiple sources and how difficult it was to access accurate reports, referring to Portolá's observations, which he had previously rejected:

The coast of California was drawn with great difficulty because of the differences in pilots's reports and other documents. In 1770, two expeditions were undertaken, one by land and one by sea, to the port of Monterrey, and I have seen the resulting map, which is different to mine; but the secrecy with which it is kept by those who have obtained a copy has not made it possible for me to use it to implement the necessary corrections.

The map's technical quality and refinement, especially with astronomical elements which increased its authority and utility, making it contrastable with additional scientific instruments, did not prevent Alzate's work from accumulating new layers of data and annotations. It was no longer an assemblage of images, but a superposition of figures that vindicated - rather confusingly - the scientific status of the map. In 1775 , over the recently corrected tip of California, Alzate synthesised several observations in a format that was not easily understandable to non-specialists: "Mission San José, north of Cape San Lucas, is, according to French and Spanish observations, at 23 degrees and 4 minutes; Don Joaquín Velázquez disagrees by 12 minutes; the western longitude from Paris meridian is 7 hours 28 minutes 7 seconds." Inconsistencies in the graphic translation of these figures is constant: in the Plano de las Provincias, the southernmost point is at $23^{\circ} \mathrm{N}$ exactly, while in the 1775 maps it is at $23^{\circ} 15^{\prime} \mathrm{N}$ (but in his previous maps, it was at slightly further to the south than $22^{\circ} \mathrm{N}$ ).

In the very same place where the Academy had placed its cartouche with the notes on the transit of Venus done by the French commission, Alzate added in his 1775 maps other observations to verify the longitude and latitude of Mexico: an explicit "astronomical turn" that backed his new cartography. For the longitude, he compared the beginning of the immersion of the first satellite of Jupiter on 30 April 1772, between Paris and Mexico City, deducing a difference of $6 \mathrm{~h} 46^{\prime}$ ' $"$ '. Without translating this into degrees, he warned that "all other observations [made by others] are different by only a few seconds, but until now the difference [between both cities] was believed to be $7 \mathrm{~h} 4$,." The latitude was verified by observing the star Rigel in January 1771. By applying a number of corrections, he established that the latitude of

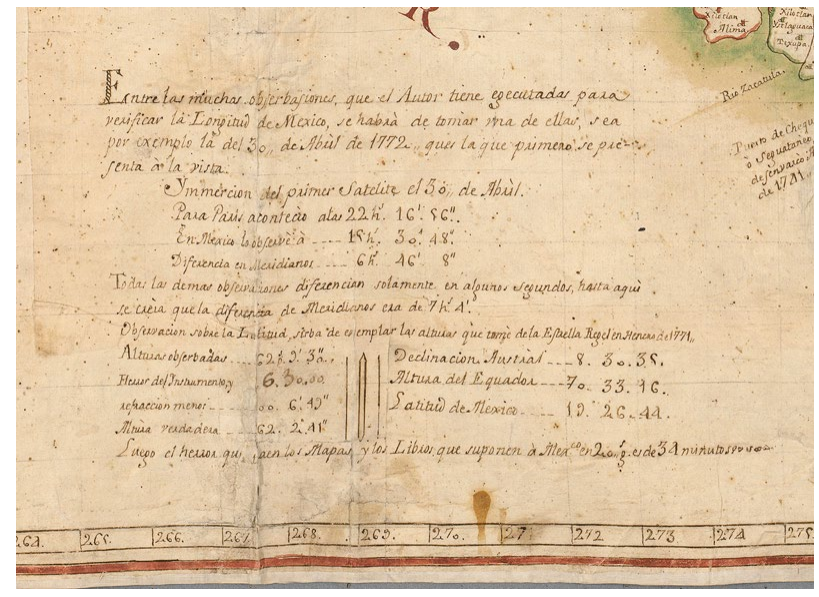

Figure 27. Cartouche detail in Alzate, Plano geografico de la mayor parte de la America Septentrional Española, 1775. British Library, London. Reproduced with permission.

Mexico City was $19^{\circ} 26^{\prime} 44^{\prime \prime}$ and stated that "the mistake of those maps and books that place Mexico City at 20 degrees is 34 minutes" (Fig. 27). ${ }^{57}$

Alongside this scientific and astronomical argument, the author - who displays his technical proficiency and his ability to access recent French material- recovers the myths and geographical fantasies about the northwest mentioned above: for Alzate, maps, as scientific instruments, could be done in more than one way. Cartographic products had to adapt to the interests of their potential readers. For Alzate, the map was not necessarily a "pure" instrument, but an artefact which is a "representation" of knowledge, and therefore an ever-transforming construct. In fact, the "astronomical turn" in the 1775 maps can be interpreted as an imitation of the French cartographic style. By keeping all layers of geographical information on display, the final appearance of maps was an aesthetically agreeable representation (to a greater or lesser extent), a conjunction of images with which to please the viewer's eye and boost the author's ego.

If the first map was dedicated to Archbishop Lorenzana, Alzate's later strategy was to address a select group of rich and politically influential Spaniards in New Spain, all of whom were members of the Sociedad Bascongada de Amigos del País, of which Alzate was already a member by 1773 . The map in the British Library was made "for the use of Don Domingo Arangoiti, Criminal prosecutor in Mexico's Audiencia." Arangoiti had been a member of the society since 1773 . The Plano of the north-western provinces, theoretically dated to 1772 , was dedicated to Juan José de Echeveste y Arrieta, head of the administration of pólvora y naipes, knight of the Order of Santiago since 1766 , member of the Bascongada since 1773, and financial administrator of military expeditions to Sonora (1771) and Alta California (1775). Alzate also gained the support of other members of the Sociedad Bascongada, whom he praised in some of his works (Torales Pacheco, 2001, pp. 191-220); for instance, Melchor de Peramás, chamber secretary of Viceroy Bucarilli, to whom he dedicated his 1772 Plano de la Ymperial México (García Re- 
dondo, 2019, p. 1003), and the Count of Tepa, Francisco Leandro de Viana Vehena, member of Mexico's Audiencia and member of the Council of the Indies since 1776, to whom he presented a map which was later used by the geographer Tomás López in Spain.

In 1783, the Spanish printer Antonio de Sancha published in Madrid a carefully edited edition of Antonio de Solís's Historia de la Conquista de México. The work included two maps of Mexico engraved by Tomás López. One was the Mapa geográfico de una parte de Nueva España (Fig. 28), and it represented the territories traversed by Cortés, and the other "the lakes, rivers and places around Mexico City." The other was conceived "to read the Historia", but López reckoned that the places mentioned in the book were very few: "they do not fill the map, and in order to make it look less naked, making it useful and complete, it was decided to fill it without confusion with places, rivers and mountain ranges which are but little known in Europe."

In a prologue about "the documents and sources on which the two maps of this book were based", López explained that he had used the following: Cortés's Historia de Nueva España (Lorenzana, 1770); a manuscript map "of this part of America, more exact than any before", facilitated by Luis Surville, first officer of the Archivo de la Secretaría de Estado and the Despacho Universal de Indias, "which was the main source"; and a large manuscript map "lent by the illustrious Count of Tepa, made for him by Don Joseph Antonio Alzate y Ramírez" (López, 1783, pp. XLIII-XLVI), acknowledgement that we have not found in any known copy. After quoting a legend similar to one of those written in the cartouches of the 1775 version, López compared Alzate's manuscript to the Académie's printed version. In his judgement, the map published by Buache would be more accurate "should the necessary corrections in the interior, and especially the coast, be implemented." However, when López had the

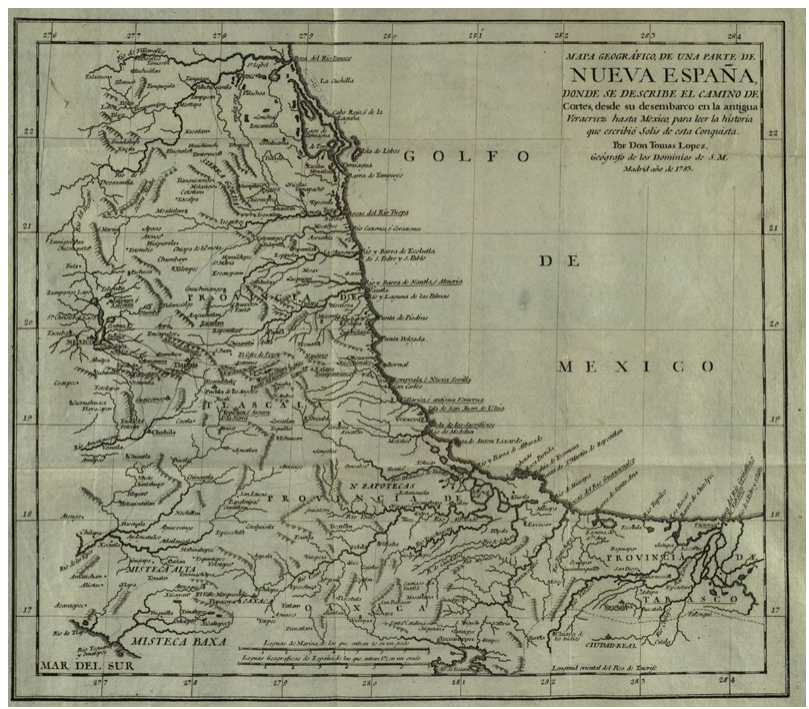

Figure 28. Tomás López, Mapa geográfico de una parte de Nueva España, published in Antonio de Solís, Historia de la Conquista de México, 1783. opportunity to engrave his version of the map published by the Académie (Fig. 23), he did not introduce said corrections. However, he did amend the coordinates for the Historia de la Conquista de México's maps: "I have preferred to use Mexico's latitude and longitude as they result from the observations of the transit of Venus carried out in California"; but he counted them not from the El Hierro meridian but rather the meridian that passed over the Mount Teide, in Tenerife. Surprisingly, the geographer did not take the coordinates that featured in the correction table inserted by Buache in the Académie's map, but the wrong ones that appear on the actual map. He took the longitude of Mexico (275'40' instead of the $278^{\circ} 16^{\prime} 30^{\prime \prime}$ that appears in the cartouche) as "duly amended." As such, by changing to a different reference meridian, the capital of New Spain was placed at $276^{\circ} 42^{\prime}$ (Fig. 28), one degree and two minutes to the east of Alzate's own reckoning in 1768 (López, 1783, p. XLV). ${ }^{58}$

\section{CONCLUSIONS}

Although Alzate used cartography to boost his prestige as a scientist, he lost control over his maps on the other side of the ocean, where they underwent versions, criticism and praise. Twisting the facts a little, he cited Tomás López's prologue as "praise" of his work, and he claimed to have "reformed geography [of New Spain] concerning longitude." He said that Mexico City's coordinates in more recent, accurate maps "are based on my observations, which the French Academy in Paris has accepted." Owing to lack of evidence, it is impossible to tell whether his map was really used "for the territorial division of the administration", as he stated..$^{59}$ Despite all of this, his geographical research did not satisfy Humboldt (1811b, I, p. 37), who saw in it "more zeal than aptitude." In the late $18^{\text {th }}$ century, these processes of circulation between America and Europe fostered a dynamic status of cartography. Alzate's corrections to his map of New Spain, from the 1766 prototype to the 1775 version, along with the autonomous life of these images once they went through different users and formats, underline the circulation of these maps and the associated processes of correction, revision, validation and refutation based on new sources and observations. Linked to this, there was also a change in the strategies of representation, and the adaptation of images to new audiences. The reception of these cartographic replicas and the incorporation of a Creole scientist in a global network of scholars brought about his reflections on the tasks of a cartographer (the use of reliable sources and the importance of astronomic observations), which enhanced an apparent scientific turn of his cartography: a refinement of the map towards an neater, more accurate image or, maybe, a different imitation of what he perceived as a conventionalism that was due to please his audience (just as he did in his first works with "images full of things"). The evolution of Alzate's "cartographic model" is nothing but a reflection of the fact that he wanted his map to be universally recognised: the adoption of the discipline's conventions, the increasing 
use of blank spaces, the critical silences and the stress on theoretical-practical application, which are characteristic of a scientific landscape increasingly dominated by experimentation.

\section{ACKNOWLEDGEMENTS}

I wish to thank the staffs of the following libraries and repositories: Bibliothèque d'Institut de France, Bibliothèque Nationale de France, Beinecke Rare Book and Manuscript Library at Yale University, British Library, and Museo Naval de Madrid.

This article is part of the research $\mathrm{R}+\mathrm{D}+\mathrm{i}$ Project CARTOPOLIC "Cartografías en movimiento. Circulación y construcción de los saberes geográficos en las monarquías policéntricas ibéricas" (UPO-1260972), which is under my direction and is funded by European Regional Development Fund (ERDF), Operational Programme 2014-2020 Junta de Andalucía. It is also a product of the ongoing project REXPUBLICA "A Monarchical Res Publica. The Spanish Monarchy, A Polycentric Imperial Structure of Urban Republics" (PGC2018095224-B-I00) and VISUALRACE "Science, Racism and Visual Colonialism" (PID2020-112730GB-I00), financed by Spanish Ministry of Economy and Competitiveness within the ERDF.

\section{NOTES}

1 José Antonio de Alzate y Ramírez, "Geografía", Gazeta de Literatura, 22 January 1793, in Alzate y Ramírez, 1831, III, pp. $59-60$

2 Ibidem, pp. 59-66. José Antonio de Alzate y Ramírez, "Estado de la Geografía de la Nueva España y modo de perfeccionarla", Asuntos Varios sobre Ciencias y Artes, 7 December 1772, in Alzate y Ramírez, 1831, IV, pp. 123-131.

3 José Antonio de Alzate (1768), Nuevo Mapa Geographico de la America Septentrional, perteneciente al virreynato de Mexico, dedicado a los sabios miembros de la Academia Real de las Ciencias de Paris, por su muy rendido servidor y capellan don Joseph Antonio de Alzate y Ramírez, año de 1768, Bibliothèque d'Institut de France, Paris, Ms 2721, n. ${ }^{\circ} 54$.

4 José Antonio de Alzate y Ramírez, "Lettre d'Alzate à l'Académie Royale des Sciences (4 et 8 mars 1770)", Archives de l'Académie des Sciences, Pochette de Séance du 15 décembre 1770, in Bret, 2001, p. 188. Patrice Bret (2001) transcribed and published Alzate's records in the Paris Académie des Sciences, which are originally in Spanish and French. For the sake of simplicity, this article cites the documents by their original author, and translates them into English based on Bret's transcription.

5 José Antonio de Alzate y Ramírez, "Estado de la Geografía de la Nueva España y modo de perfeccionarla", Asuntos Varios sobre Ciencias y Artes, 7 December 1772, in Alzate y Ramírez, 1831, IV, p. 127.

6 José Antonio de Alzate y Ramírez, "Lettre d'Alzate à l'Académie Royale des Sciences (4 et 8 mars 1770)", Archives de l'Académie des Sciences, Pochette de Séance du 15 décembre 1770, in Bret, 2001, p. 197.

7 Ibidem, pp. 187-189.

8 José Antonio de Alzate y Ramírez, "Estado de la Geografía de la Nueva España y modo de perfeccionarla", Asuntos Varios sobre Ciencias y Artes, 7 December 1772, in Alzate y Ramírez, 1831, IV, pp. $125,129$.

9 José Antonio de Alzate y Ramírez, "Lettre d'Alzate à l'Académie Royale des Sciences (4 et 8 mars 1770)", Archives de l'Académie des Sciences, Pochette de Séance du 15 décembre 1770, in Bret, 2001, p. 188.

10 Ibidem, p. 189.

11 In addition to presenting himself to the Académie (which appointed him corresponding member in March 1771), in 1790 he asked Charles IV to appointment him Royal Chronicler of New Spain. This application was rejected by the Madrid Real Academia de la Historia. For his participation in the public life of New Spain, see Saborit (2018). For his cartographic production within the context of New Spain, see Mendoza Vargas (2000); Moncada Maya (2003)

12 For the materials that Alzate sent to the Académie, see Bret (2001, pp. 151-170). The natural history collection was published in Chappe d'Auteroche (1772) by Jean-Dominique Cassini. The same work included a Plan de la Ville de Mexico, which was based on 1769 Alzate's city map (García Redondo, 2019, pp. 1033-1035).

13 Domingo del Castillo's original map, found in the archive of the Marquis of Valle, is now lost. When he copied it for its publication in Lorenzana (1770) (Fig. 3), Alzate was forced to change some of the cartouches: "this note is not mine, it is partly mistaken, and the person who published it is my superior [...] no note is found in the original, and the editor did not wish the cartouche to go there" (José Antonio de Alzate y Ramírez, "Lettre d'Alzate à l'Académie Royale des Sciences (4 et 8 mars 1770)", Archives de l'Académie des Sciences, Pochette de Séance du 15 décembre 1770, in Bret, 2001, p. 189). Probably, the manuscript copy, kept in the Biblioteca de la Real Academia de la Historia, Madrid, C-011-004-04, and dated to 1778 according to Carmen Manso Porto (2014, pp. 37-38), is closer to the original that Alzate saw. Available at: http://bibliotecadigital.rah.es/es/ consulta/registro.do?id=12801 [Accessed 20 April 2020]. For Lorenzana's editorial project, see Sarabia (2002).

14 José Antonio de Alzate y Ramírez, "Lettre d'Alzate à l'Académie Royale des Sciences (4 et 8 mars 1770)", Archives de l'Académie des Sciences, Pochette de Séance du 15 décembre 1770, in Bret, 2001, p. 188.

15 José Antonio de Alzate (1769), Plano de la Nueva España en que se señalan los viages que hizo el capitán Hernán Cortés, así antes como después de conquistado el Imperio Mexicano (Fig. 4). Engraved by José Mariano Navarro for Lorenzana (1770).

16 José Antonio de Alzate (1767), Nuevo Mapa Geográphico, el más completo y acotado de cuantos se han publicado de la América Septentrional Española, dividida en Obispados y Provincias, Museo Naval, Madrid (MN), 7-A-8 (177 x $210 \mathrm{~cm}$ ).

17 José Antonio de Alzate y Ramírez, "Estado de la Geografía de la Nueva España y modo de perfeccionarla”, Asuntos Varios sobre Ciencias y Artes, 7 December 1772, in Alzate y Ramírez, 1831, IV, p. 126.

18 Idem.

19 Ibidem, p. 128.

20 An old version of Villaseñor's map survives. It is entitled Yconismo hidrotérreo, o Mapa Geográphico de la America Septentrional. Delineado y observado por el Contador de los Reales Azogues D. José Antonio de Villaseñor y Sánches, and was engraved by Francisco Sylverio de Sotomayor in 1746 $(52.5 \times 71.5 \mathrm{~cm})$, Archivo General de Indias, Sevilla (AGI), Mapas y Planos, México, 161. Available at: http://pares.mcu. es/ParesBusquedas20/catalogo/description/20997 [Accessed 20 April 2020]. Later, Alzate quoted, among the "useful" maps for the geography of New Spain, those by the engineers Miguel Constanzó and Nicolás Lafora, for the geography of the north; the maps commissioned by Governor José de Escandón, for New Santander, and maps of Puebla commissioned by Bishop Lardizábal, as well as several reports written for Michoacán and Durango (Ibidem, p. 129).

21 Ibidem, pp. 125-126).

22 Sigüenza's map covered from $13^{\circ} 30^{\prime}$ to $30^{\circ} 30^{\prime} \mathrm{N}$ and from $268^{\circ}$ to $291^{\circ}$ West, counting from the Santa Cruz meridian, Canarias. This left out of the map much of Yucatán and the peninsula of California, of which only the southern tip featured (Sánchez Lamego, 1955, p. 23). For Sigüenza's cartographic work, see 
Codding (1994, p. 214, n. 2). Pablo Beaumont's version, which is the one reproduced here (Fig. 6), was drawn in approximately 1778, but remained unpublished until 1873: Descripción de esta Parte de la America Septentrional, esto es de lo que se llama Nueva España, y de sus Provincias descubiertas y pobladas; según el plano Geográfico que sacó el año de 1641 [sic] Don Carlos Siguenza y Góngora enmendado y renovado por el Autor de este Aparato a la Chronica de Mechoacan, MN, 7-A6. Available at: http://bibliotecavirtualdefensa.es/BVMDefensa/ i18n/consulta/registro.cmd?id=45470 [Accessed 20 April 2020].

23 Carlos de Sigüenza's original cordilleras have not survived (Sánchez Lamego, 1955, pp. 27-28; Trabulse, 1988, pp. 72 74), but other versions are known (although they are not entirely identical to Alzate's): those of Juan Francisco Sahagún de Arévalo Ladrón de Guevara (published in Gazeta de México, 1730-1731) and Pablo Beaumont, also transcribed on his version of Sigüenza's map (Codding, 1994, pp. 192-193; Trabulse, 2001, pp. 272-274). Alzate added six new roads leading to northern cities and presidios [fortresses].

24 José Antonio de Alzate y Ramírez, "Geografía", Gazeta de Literatura, 22 January 1793, in Alzate y Ramírez, 1831, III, pp. 59-66.

25 Ibidem, pp. 59-61.

26 Ibidem, p. 60

27 Pierre Charles Lemonnier and Philippe Buache, "Rapport de Le Monnier et Buache sur la carte d'Alzate (3 août 1768)", Archives de l'Académie des Sciences, Pochette de Séance du 22 juin 1768, in Bret, 2001, p. 182.

28 José Antonio de Alzate y Ramírez, "Estado de la Geografía de la Nueva España y modo de perfeccionarla", Asuntos Varios sobre Ciencias y Artes, 7 December 1772, in Alzate y Ramírez (1831, IV, pp. 128-129).

29 Pierre Charles Lemonnier and Philippe Buache, "Rapport de Le Monnier et Buache sur la carte d'Alzate (3 août 1768)", Archives de l'Académie des Sciences, Pochette de Séance du 22 juin 1768, in Bret, 2001, p. 182.

30 "En este Golfo se puede conocer la distancia en que se halla uno de la tierra por la sonda porque v. gr. si ay siete brazadas de agua es señal de hallarse siete leguas de distancia de la costa, así lo afirma Guillermo Le Ysla en su Mapa.'

31 Probably, Alzate also used Guillaume Delisle's Carte de la Louisiane et du Cours du Mississipi (París, 1718), which is much more detailed than the 1722 version, for the northern profile of the Gulf of Mexico and the territory of Louisiana. Some degree of similarity between both maps exists concerning the Gulf's northern coastline, the mouth of the Mississippi, the course of various rivers and several historical references (which are written in the same position), such as the arrival of Hernando de Soto to Florida in 1539 or the founding of Natchitoches (in Louisiana) by the French in 1717. Both of Delisle's maps were edited and printed in multiple occasions.

32 José Antonio de Alzate (1768), Nuevo Mapa Geographico de la America Septentrional, perteneciente al virreynato de Mexico, dedicado a los sabios miembros de la Academia Real de las Ciencias de Paris, por su muy rendido servidor y capellan don Joseph Antonio de Alzate y Ramírez, año de 1768, Bibliothèque d'Institut de France, Paris, Ms 2721, n. ${ }^{\circ} 54$.

33 In order to solve the problem posed by the large number of meridians used by European cartographers since the Renaissance, in 1634 Louis XIII published an edict instructing French geographers to use the El Hierro (the westernmost island of the Canaries) meridian, which was approximately $20^{\circ}$ to the west of the Paris meridian; longitude is counted from these meridians eastwards (Broc, 1975, p. 23). Afterwards, several expeditions to El Hierro, including one led by the astronomer Louis Feuillé and sponsored by the Académie in 1724, refined these measurements (Puig-Samper and Pelayo, 1997; Tous Meliá, 2002).

34 Pierre Charles Lemonnier and Philippe Buache, "Rapport de Le Monnier et Buache sur la carte d'Alzate (3 août 1768)", Archives de l'Académie des Sciences, Pochette de Séance du 22 juin 1768, in Bret, 2001, pp. 181-183.

35 Idem.
36 Between 1724 and 1730, Álvarez Barreiro drew several maps of the northern territories of Nueva España. The general map, Plano Corographico e Hidrographico de las Provincias del Nuevo Mexico (1729), is kept at the Hispanic Society of America, New York, and it measures 51 x $89 \mathrm{~cm}$. Multiple later versions exist, one of them was printed in Madrid by Juan López in 1803: Mapa geográfico de las provincias al norte de Nueva España. Six regional maps are known in AGI, Mapas y Planos, México, 120-125, representing Nuevo Reino de Toledo; Nueva Vizcaya and Culiacán; Nuevo México; Sonora and Sinaloa; Nueva Extremadura and Nuevo de León; and a plan of the harbour of Acapulco. There is also evidence for a map of Texas, now lost (Cohen, 2002, p. 55).

37 José Antonio de Alzate y Ramírez, "Estado de la Geografía de la Nueva España y modo de perfeccionarla", Asuntos Varios sobre Ciencias y Artes, 7 December 1772, in Alzate y Ramírez, 1831, IV, p. 128

38 José Antonio de Alzate y Ramírez, "Lettre d'Alzate à l'Académie Royale des Sciences (4 et 8 mars 1770)", Archives de l'Académie des Sciences, Pochette de Séance du 15 décembre 1770, in Bret, 2001, p. 187.

39 Philippe Buache's manuscript copy (1768) of Nuevo Mapa Geographico de la America Septentrional, perteneciente al virreynato de Mexico (José Antonio de Alzate, 1768). Bibliothèque Nationale de France, Paris (BNF), département Cartes et plans, Ge B 1187 (89 x 69 cm). Available at: https://gallica.bnf.fr/ ark:/12148/btv1b525089172 [Accessed 20 April 2020]. At the top of the tracing, the following sentence has been added: "Titre figuré du Titre de la copie remise a M. l'Abbé Chappe d'Auteroche."

40 Philippe Buache's manuscript copy (1768) of Nuevo Mapa Geographico de la America Septentrional, perteneciente al virreynato de Mexico (José Antonio de Alzate, 1768), with the authorisation and handwritten signature of the Grand Jean Defouchy (on sheet 76 x $84 \mathrm{~cm}$ ). Beinecke Rare Book and Manuscript Library, Yale University, New Haven, BrSides Elephant Folio 2018 13, Image ID 16685693. Available at: https://brbl-dl. library.yale.edu/vufind/Record/4671938 [Accessed 25 September 2020].

41 José Antonio de Alzate y Ramírez, "Estado de la Geografía de la Nueva España y modo de perfeccionarla”, Asuntos Varios sobre Ciencias y Artes, 7 December 1772, in Alzate y Ramírez, 1831, IV, pp. 124-125.

42 Pierre Charles Lemonnier and Jean Dominique Cassini, "Rapport de Le Monnier et Cassini fils sur la carte d'Alzate gravée par Buache (15 février 1772)", Archives de l'Académie des Sciences, Pochette de Séance du 15 février 1772, in Bret, 2001, pp. 204-205.

43 Ibidem, p. 205.

44 Nuevo Mapa Geographico de la America Septentrional, perteneciente al virreynato de Mexico, dedicado a los sabios miembros de la Academia real de las ciencias de Paris por... Joseph Antonio de Alzate y Ramirez. Año de 1768, printed in Paris by the Buaches in 1772. Copy with the patch on the top left corner: BNF, Cartes et plans, GE C-4643 $(68$ x $55 \mathrm{~cm})$. Available at: https://gallica.bnf.fr/ark:/12148/btv1b53064648z [Accessed 20 April 2020]. Another version of the patch pasted on the cartouche: BNF, département Arsenal, EST-1504 (13), available at: https://gallica.bnf.fr/ark:/12148/btv1b53171218r [Accessed 20 April 2020]. A handwritten "1772" in this last copy marks the date of the first printed version of the map, which has sometimes been wrongly dated. See a map with the overwritten date in BNF, Cartes et plans, GE C-10971, available at: https://gallica. bnf.fr/ark:/12148/btv1b531024980 [Accessed 20 April 2020]. For the few known printed copies of Alzate's maps, see Brown (2019, p. 25, n. 2).

45 Carte de Fausses Positions de Mexico, Acapulco, Veracruz et du Pic d'Orizaba. Dessiné par A. de Humboldt à Mexico 1804. Gravé par L. Aubert, published in Humboldt, 1811a. Available at: https://www.davidrumsey.com/luna/servlet/detail/ RUMSEY 8 1 1875 170013:Carte-de-Fausses-Positions-deMexic [Accessed 20 April 2020]. 
46 Nuevo Mapa Geographico de la America Septentrional [...] Alzate [...] 1768, printed in Paris by Dezauche (after 1780), $(60 \times 73 \mathrm{~cm})$. Baylor University, Waco (Texas), Texas Collection, Texas Frances C. Poage Map Room (Room 201). "À Paris, Chez Dezauche, graveur, successeur et possesseur du Fond Géographique des Srs. De Isle et Buache, premiers Géographes du Roi, Rue des Noyers près celle des Anglois."

47 Nuevo Mapa geográfico de la América Septentrional, perteneciente al Virreynato de México, dedicado a los sabios miembros de la Academia Real de las Ciencias de París por su mui rendido servidor y capellan, D. Josef Antonio de Alzate y Ramirez. Año de 1768, printed in Madrid by Tomás López (after 1790), (54 x $66 \mathrm{~cm}$; each sheet, 27 x $33 \mathrm{~cm})$. Available at: https://purl. stanford.edu/nx789xc8027 [Accessed 20 April 2020].

48 Nuevo Mapa geográfico de la América Septentrional..., printed in Madrid by Tomás López (after 1792), (53 x $64.2 \mathrm{~cm}$ ), with printer's mark: "Se hallará en Madrid, calle de Atocha, frente la casa de los Gremios." Beinecke Rare Book and Manuscript Library, Yale University, New Haven, 88 1768, Image ID: 15823111. Available at: https://brbl-dl.library.yale.edu/vufind/ Record/4218034 [Accessed 20 April 2020].

49 José Antonio de Alzate y Ramírez, "Geografía”, Gazeta de Literatura, 22 January 1793, in Alzate y Ramírez, 1831, III, pp. 59-60.

50 José Antonio de Alzate y Ramírez, "Estado de la Geografía de la Nueva España y modo de perfeccionarla", Asuntos Varios sobre Ciencias y Artes, 7 December 1772, in Alzate y Ramírez, 1831, IV, pp. 130-131.

51 Ibidem, p. 129.

52 José Antonio de Alzate (c. 1772), Plano de las Provincias de Ostimuri, Sinaloa, Sonora y demás circunvecinas y parte de $\mathrm{Ca}$ lifornia dispuesto por Don Joseph Antonio de Alzate y Ramírez; del uso del Señor Don Juan Joseph de Echevestre, caballero del Orden de Santiago, etc., etc. En México año de 1772, Mapoteca Manuel Orozco y Berra, Mexico City, 266-OYB-7221-A (55 x $42 \mathrm{~cm}$ ).

53 José Antonio de Alzate y Ramírez, "Lettre d'Alzate à l'Académie Royale des Sciences (4 et 8 mars 1770)", Archives de l'Académie des Sciences, Pochette de Séance du 15 décembre 1770 , in Bret, 2001, p. 188.

54 José Antonio de Alzate (Oct. 22, 1775), Plano geografico de la mayor parte de la America Septentrional Española, MN, 7-A-9 $(106 \times 85 \mathrm{~cm})$. José Antonio de Alzate (Nov. 14, 1775), Plano geográfico de la mayor parte de la America Septentrional Española, British Library, London, Cartographic Items Additional MS. 17,648.a. (114 x $86 \mathrm{~cm})$

55 José Antonio de Alzate y Ramírez, "Prólogo de Mr. Fontenelle", Observaciones sobre la Física, Historia Natural y Artes Útiles, 1787, in Alzate y Ramírez, 1831, IV, p. 194.

56 José Antonio de Alzate y Ramírez, "Lettre d'Alzate à l'Académie Royale des Sciences (4 et 8 mars 1770)", Archives de l'Académie des Sciences, Pochette de Séance du 15 décembre 1770, in Bret, 2001, p. 188

57 In the Museo Naval version, the "error del instrumento" employed for the observation of the latitude was left blank. This figure (6 30 '00') was added later in the British Library map.

58 We do not know whether Tomás López was referring to the map owned by the Count of Tepa or the printed Nuevo Mapa Geográfico when, in 1801, he said that the Mapa Geográfico del Obispado de Mechoacán had been made "por el manuscrito del Br. D. Manuel Ygnacio Carranza, el de D. Josef Antonio de Alzate y Ramírez, y otros documentos" (Líter and Sanchís, 1998, p. 17). A copy of this map is kept in AGI, Mapas y Planos, México, 483. Available at: http://pares.mcu.es/ParesBusquedas20/ catalogo/description/21419?nm [Accessed 20 April 2020].

59 José Antonio de Alzate y Ramírez, "Prólogo de Mr. Fontenelle", Observaciones sobre la Física, Historia Natural y Artes Útiles, 1787, in Alzate y Ramírez, 1831, IV, p. 194. José Antonio de Alzate y Ramírez, "Méritos, servicios, obras escritas y publicadas y comisiones particulares del presbítero don José Antonio de Alzate y Ramírez, residente en México", 1790, in Moreno de los Arcos, 1985, pp. 141-143.

\section{REFERENCES}

Achim, M., ed. (2012) Observaciones útiles para el futuro de México. Selección de artículos, 1768-1795. José Antonio Alzate. México: Conaculta.

Altić, M. S. (2012) "Ferdinand Konšćak: Cartographer of the Compañia de Jesús and his Maps of Baja California." In: E. Liebenberg and I. J. Demhardt, eds., History of Cartography. International Symposium of the ICA Commission, 2010. Heidelberg: Springer, pp. 3-20.

Alzate y Ramírez, J. A. (1770) Eclypse de Luna del doce de diciembre de mil setecientos sesenta y nueve años. Observado en la Imperial Ciudad de México. México: Joseph Jáuregui.

Alzate y Ramírez, J. A. (1831) Gacetas de Literatura de México. Puebla: Oficina del Hospital de San Pedro.

Arribas y Soria, J. and Velasco, J., eds. (1792) Encyclopedia Metódica: Geografía Moderna. Madrid: Imprenta de Sancha.

Belidor, B. F. (1737) Architecture hydraulique, ou l'art de conduire, d'élever, et de menager les eaux pour les différens besoins de la vie. Paris: Charles Antoine Jombert.

Bernabéu Albert, S. (1991) "La frontera califórnica: de las expediciones cortesianas a la presencia convulsiva de Gálvez (15341767).' In: F. Solano and S. Bernabéu, eds., Estudios (nuevos y viejos) sobre la frontera. Anexos de Revista de Indias. Madrid: CSIC, pp. 85-118.

Bernabéu Albert, S. (1998) Las huellas de Venus. El viaje del astrónomo Chappe d'Auteroche a Nueva España (1768-1769). México: Breve Fondo Editorial.

Besse, J. M., Blais, H. and Surun, I., eds. (2010) Naissances de la géographie moderne (1760-1860). Lyon: ENS Éditions.

Binková, S. (2007) "Mover las fronteras: los jesuitas bohemios en México que participaron en las expediciones a los ríos Gila y Colorado (Adán Gilg, Ignacio Xavier Keller y Wenceslao Linck)." In: K. Kohut and M. C. Torales Pacheco, eds., Desde los confines de los imperios ibéricos. Los jesuitas de habla alemana en las misiones americanas. Madrid/Frankfurt: Iberoamericana/Vervuert, pp. 443-480.

Bleichmar, D. (2012) Visible Empire. Botanical Expeditions and Visual Culture in the Hispanic Enlightenment. Chicago: University of Chicago Press.

Bond, E. A. (1868) Catalogue of additions to the manuscripts in the British Museum in the years 1848-1853. London: British Museum.

Brading, D. (1991) The First America: The Spanish Monarchy, Creole Patriots, and the Liberal State, 1492-1867. Cambridge: Cambridge University Press.

Bret, P. (2001) "Alzate y Ramírez et l'Académie Royale des Sciences de Paris: La réception des travaux d'un savant du Nouveau Monde.” In: P. Aceves Pastrana, ed., Periodismo científico en el siglo XVIII: José Antonio de Alzate y Ramírez. México: Universidad Autónoma Metropolitana, pp. 123-205.

Broc, N. (1975) La géographie des philosophes. Géographes et voyageurs français au XVIII ${ }^{e}$ siècle. Paris: Editions Ophrys.

Brown, W. (2019) "Nuevo Mapa Geográfico de la América Septentrional. José Antonio de Alzate y Ramirez's remarkable map of New Spain." IMCOS. Journal of the International Map Collectors' Society, 156, pp. 11-26.

Buache, P. (1754) Considerations Geographiques et Physiques sur les Nouvelles Decouvertes au Nord de la Grande Mer, appelèe vulgairement la Mer du Sud avec des Cartes qui y sont relatives. Paris: Académie Royale des Sciences

Burriel, A. M. (1757) Noticia de la California, y de su conquista temporal, y espiritual hasta el tiempo presente. Sacada de la historia manuscrita formada en México año de 1739 por el padre Miguel Venegas. Madrid: Viuda de Manuel Fernández.

Burrus, E. J. (1967) La obra cartográfica de la Provincia Mexicana de la Compañía de Jesús (1567-1967). Madrid: Ediciones de José Porrúa Turanzas.

Cañizares-Esguerra, J. (2002) How to Write the History of the New World. Histories, Epistemologies, and Identities in the Eight- 
eenth-Century Atlantic World. Stanford: Stanford University Press.

Carrera, M. M. (2011) “Creole Landscapes.” In: J. Dym and K. Offen, ed., Mapping Latin America: A Cartographic Reader. Chicago: University of Chicago Press, pp. 110-113.

Chappe d'Auteroche, J. B. (1772) Voyage en Californie pour la observation du Passage de Vénus sur le disque du Soleil, le 3 Juin 1769 [...] Rédigé et pubié par m. de Cassini fils. Paris: Chez Charles Antoine Jombert.

Clark, F. (2009a) "Nothing Ventured, Nothing Gained: Lightning and Enlightenment in the 'Gazeta de Literatura de México' (1788-1795)." Transactions of the American Philosophical Society, 99.5, pp. 71-93. Available at: https://www.jstor.org/ stable/27757456 [Accessed 17 Feb. 2020].

Clark, F. (2009b) “'Read All About It': Science, Translation, Adaptation, and Confrontation in the Gazetas de Literatura de México, 1788-1795.' In: D. Bleichmar, P. De Vos, K. Huffine and K. Scheehan, eds., Science in the Spanish and Potuguese Empire, 1500-1800. Stanford: Stanford University Press, pp. 147-177.

Codding, M. A. (1994) "Perfecting the Geography of New Spain: Alzate and the Cartographic Legacy of Sigüenza y Góngora." Colonial Latin American Review, 3, pp. 185-219. doi: https:// doi.org/10.1080/10609169408569828

Cohen, P. E. (2002) Mapping the West. America's Westward Movement 1524-1890. New York: Rizzoli.

Conley, T. (1997) The Self-Made Map. Cartographic Writing in Early Modern France. Minneapolis: University of Minnesota Press.

Dawson, N. M. (2000) L'atelier Delisle: l'Amérique du Nord sur la table à dessin. Sillery, Québec : Éditions du Septentrion.

Esteve Barba, F. (1942) Catálogo de la colección de manuscritos Borbón-Lorenzana. Biblioteca Pública de Toledo. Madrid: Imprenta Góngora

García Redondo, J. M. (2018) "Las representaciones geográficas de la archidiócesis de México en tiempos del arzobispo Lorenzana (1766-1772)." Estudios de Historia Novohispana, 59, pp. 26 73. doi: https://doi.org/10.22201/iih.24486922e.2018.59.63115

García Redondo, J. M. (2019) "El proceso cartográfico de la reforma parroquial del arzobispo Lorenzana: propuestas planimétricas de José Antonio de Alzate y recreación ilustrada de la ciudad de México (1767-1772)." Historia Mexicana, 68, pp. 1001-1073. doi: https://doi.org/10.24201/hm.v68i3.3810

García Rojas, I. B. (2017) "Senderos de la marginalia e iconografía cartográfica, Nueva España siglos XVI-XVIII.” Biblio3W. Revista Bibliográfica de Geografía y Ciencias Sociales, 22, 1192 pp. 1-34. Available at: https://revistes.ub.edu/index.php/b3w/ article/view/26419/27833 [Accessed 17 Feb. 2020].

Gerbi, A. (1973) The Dispute of the New World: The History of a Polemic, 1750-1900. Pittsburgh: University of Pittsburgh Press.

Godlewska, A. M. (1999) Geography unbound: French geographic science from Cassini to Humboldt. Chicago: University of Chicago Press.

Guillén Tato, J. (1932) Repertorio de los manuscritos, cartas, planos y dibujos relativos a las Californias, existentes en este museo. Madrid: Publicaciones del Museo Naval.

Guillén Tato, J. (1940) "El nuevo mapa del P. José de Alzate.” Revista de Indias, 1, pp. 197-202.

Harvey, P. D. A. (1980) Topographical Maps. The History of Topographical Maps: Symbols, Pictures and Surveys. London: Thames and Hudson.

Hernando Rico, A. (2008) El geógrafo Juan López (1765-1825) y el comercio de mapas en España. Madrid: CSIC.

Humboldt, A. (1811a) Atlas géographique et physique du royaume de la Nouvelle Espagne fondé sur des observations astronomiques, des mesures trigonométriques, et des nivellemens barometriques. Paris: F. Schoell.

Humboldt, A. (1811b) Essai politique sur le Royaume de la Nouvelle-Espagne. Paris: F. Schoell.

Laboulais-Lesage, I. (2004) Combler les blancs de la carte. Modalités et enjeux de la construction des savoirs géographiques
$\left(X V I I^{e}-X X^{e}\right.$ siècle). Strasbourg: Presses Universitaires de Strasbourg. doi: https://doi.org/10.4000/books.pus.12492

Latour, B. (1987) Science in Action: How to Follow Scientists and Engineers Through Society. Cambridge: Harvard University Press.

León-Portilla, M. (2001) Cartografía y crónicas de la Antigua California. 2nd ed. México: Universidad Nacional Autónoma de México.

Líter Mayayo, C. and Sanchís Ballester, F. (1998) Tomás López y sus colaboradores. Madrid: Biblioteca Nacional.

Livingston, D. N. (2003) Putting Science in its Place. Geographies of Scientific Knowledge. Chicago: University of Chicago Press.

López, T. (1783) "Razón de los documentos y fundamentos sobre que se hicieron los dos mapas de esta obra." In: Solís, A., Historia de la conquista de México. Población y progresos de la América Septentrional conocida por el nombre de Nueva España, Madrid: Imprenta de Antonio de Sancha, pp. XLIII-XLVI.

López Gómez, A. (2000) "Los domicilios en Madrid y el éxito del geógrafo Tomás López (1731-1802).” Boletín de la Real Academia de la Historia, 197, pp. 377-392.

López Gómez, A. and Manso Porto, C. (2006) Cartografía del siglo XVIII. Tomás López en la Real Academia de la Historia. Madrid: Doce Calles.

Lorenzana, F., ed. (1770) Historia de Nueva-España escrita por su esclarecido conquistador Hernán Cortés, aumentada con otros documentos y notas. México: Imprenta del Superior Gobierno.

Manso Porto, C. (2014) "Cartografía del Mar del Sur de la Real Academia de la Historia y su relación con la historia de las Indias." Revista de Estudios Colombinos, 10, pp. 33-44.

Marcaida López, J. R. (2014) Arte y Ciencia en el Barroco español. Madrid: Marcial Pons.

Martín-Merás, M. L. (1993) Cartografía marítima hispana. La imagen de América. Madrid: Lunwerg, Ministerio de Obras Públicas, Transportes y Medio Ambiente.

Mendoza Vargas, H. (2000) "Alzate y la geografía francesa: El proyecto y las propuestas para la Nueva España.” In: T. Rojas Rabiela, ed., José Antonio de Alzate y la Ciencia Mexicana. Morelia: Universidad Michoacana de San Nicolás de Hidalgo, pp. 207-219.

Moncada Maya, J. O., ed. (2003) La geografía de la Ilustración. México: Universidad Nacional Autónoma de México, Instituto de Geografía.

Moreno Corral, M. A. (2010) "José Antonio de Alzate como astrónomo." In: S. Galindo Uribarri, M. A. Moreno Corral and A. Saladino García, eds., El astrónomo José Antonio de Alzate. México: Innovación Editorial Lagares de México, pp. 23-74.

Moreno de los Arcos, R. (1977) Joaquín Velázquez de León y sus trabajos científicos sobre el valle de México, 1773-1775. México: Universidad Nacional Autónoma de México.

Moreno de los Arcos, R., ed. (1985) José Antonio de Alzate. Memorias y ensayos. México: Universidad Nacional Autónoma de México.

Moreno de los Arcos, R. (1989) Linneo en México. Las controversias sobre el sistema binario sexual 1788-1798. México: Universidad Nacional Autónoma de México.

Moreno Martín, J. M. (2012) "Una Expedición Cartográfica por el Museo Naval." In: D. Rodríguez López, ed., Cátedra "Jorge Juan.” Ciclo de conferencias. Curso 2010-2011. A Coruña: Universidade da Coruña, pp. 139-167.

Pedley, M. S. (1992) Bel et utile. The work of the Robert de Vaugondy Family of Mapmakers. Tring, UK: Map Collector Publications.

Peset, J. L. (1987) Ciencia y libertad. El papel del científico ante la independencia americana. Madrid: CSIC.

Petto, C. M. (2007) When France was King of Cartography. The Patronage and Production of Maps in Early Modern France. Lanham/Plymouth: Lexington Books.

Pimentel, J. (2003) Testigos del mundo. Ciencia, literatura y viajes en la Ilustración. Madrid: Marcial Pons.

Pinzón, G. (2017) "El Pacífico novohispano a partir del Mapa de 
la América Septentrional de 1754.” Estudios Jalicienses, 107, pp. 18-31. Available at: https://www.estudiosjaliscienses. com/2017/02/01/num-107/ [Accessed 17 Feb. 2020].

Polk, D. B. (1995) The Island of California. A History of the Myth. Lincoln and London: University of Nebraska Press, Bison Books.

Puig-Samper, M. Á. (2017) "La medida de América: De la observación métrica ilustrada española al empirismo razonado humboldtiano." Historia Mexicana, 67, pp. 907-963. doi: https://doi.org/10.24201/hm.v67i2.3474

Puig-Samper, M. Á. and Pelayo, F. (1997) El viaje del astrónomo y naturalista Louis Feuillée a las Islas Canarias (1724). Seguido de la transcripción y traducción del manuscrito "Historia antigua y moderna de las Islas Canarias”, redactado por Louis Feuillée. La Laguna: Centro de la Cultura Popular Canaria, Ayuntamiento de La Laguna.

Rodríguez, R. C., ed. (2014) Our Sacred Maíz is Our Mother: Indigeneity and Belonging in the Americas. Tucson: University of Arizona Press.

Saborit, A. (2018) El virrey y el capellán. Revilla Gigedo, Alzate y el censo de 1790. México: Cal y Arena.

Sáenz-López Pérez, S. (2014) Marginalia in cARTography. Exhibition at the Chazen Museum of Art. Madison: University of Wisconsin.

Safier, N. (2008) Measuring the New World: Enlightenment Science and South America. Chicago: University of Chicago Press.

Saladino García, A. (2001) El sabio José Antonio Alzate y Ramírez. de Santillana. Toluca: Universidad Autónoma del Estado de México.

Saladino García, A. (2010) Dos científicos de la Ilustración hispanoamericana: J. A. Alzate y F. J. Caldas. $2^{\text {nd }}$ ed. México: Universidad Nacional Autónoma de México.

Sánchez Lamego, M. Á. (1955) El primer mapa general de México elaborado por un mexicano. México: Instituto Panamericano de Geografía e Historia.

Sarabia Viejo, M. J. (2002) "El cardenal Lorenzana, editor de textos cortesianos en el siglo XVIII.” Silva: Estudios de humanismo y tradición clásica, 1, pp. 183-212.
Schaffer, S. (2011) Trabajos de cristal. Ensayos de historia de la ciencia, 1650-1900. Madrid: Marcial Pons.

Topham, J. R. (2000) "Scientific Publishing and the Reading of Science in Nineteenth-Century Britain: A Historiographical Survey and Guide to Sources." Studies in History and Philosophy of Science, 31, pp. 559-612. doi: https://doi.org/10.1016/S00393681(00)00030-3

Torales Pacheco, M. C. (2001) Ilustrados en la Nueva España: Los socios de la Real Sociedad Bascongada de Amigos del País. México: Universidad Iberoamericana, Real Sociedad Bascongada de Amigos del País.

Tous Meliá, J. (2002) "La Isla de El Hierro y el meridiano origen." Estudios Canarios. Anuario del Instituto de Estudios Canarios, 46, pp. 249-288.

Trabulse, E. (1988) Los manuscritos perdidos de Sigüenza y Góngora. México: El Colegio de México. doi: https://doi. org/10.2307/j.ctv26d8bk

Trabulse, E. (2001) "La obra cartográfica de don Carlos de Sigüenza y Góngora.” Caravelle, 76-77, pp. 265-275. doi: https://doi. org/10.3406/carav.2001.1304

Valverde Pérez, N. (2007) Actos de precisión, instrumentos científicos, opinión pública y economía moral en la Ilustración española. Madrid: CSIC.

Velázquez de León, J. (1775) "Descripción histórica y topográfica del valle, las lagunas y ciudad de México.” In: R. Moreno (1977), Joaquín Velázquez de León y sus trabajos científicos sobre el valle de México, 1773-1775. México: Universidad Nacional Autónoma de México, pp. 183-356.

Withers, C. W. J. (2007) Placing the Enlightenment: Thinking Geographically about the Age of Reason. Chicago: University of Chicago Press.

Zamudio, G. (2012) "José Antonio Alzate: Su práctica como naturalista." In: Memorias del XXV Encuentro de Investigadores del Pensamiento Novohispano. Toluca: Universidad Autónoma del Estado de México, pp. 1-15. Available at: http://web.uaemex.

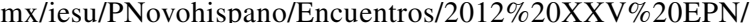
VI\%20Conmemorando\%20275\%20A/Graciela\%20Zamudio. pdf [Accessed 17 Feb. 2020]. 